\begin{abstract}
UNIVERSIDADE DE SÃO PAULO
FACULDADE DE FILOSOFIA, LETRAS E CIÊNCIAS HUMANAS

DEPARTAMENTO DE LETRAS CLÁSSICAS E VERNÁCULAS

PROGRAMA DE PÓS-GRADUAÇÃO EM LITERATURA BRASILEIRA
\end{abstract}

WANDERLEY CORINO NUNES FILHO

\title{
A poética errante de Orides Fontela
}

(versão corrigida)

São Paulo 
WANDERLEY CORINO NUNES FILHO

\title{
A poética errante de Orides Fontela
}

\author{
(versão corrigida)
}

Dissertação de mestrado apresentada ao Programa de Pós-graduação em Literatura Brasileira da Faculdade de Filosofia, Letras e Ciências Humanas, da Universidade de São Paulo, como parte dos requisitos para a obtenção do título de Mestre em Letras (Literatura Brasileira).

Orientador: Prof. Dr. Ivan Francisco Marques

São Paulo 
Autorizo a reprodução e divulgação total ou parcial deste trabalho, por qualquer meio convencional ou eletrônico, para fins de estudo e pesquisa, desde que citada a fonte.

Catalogação na Publicação

Serviço de Biblioteca e Documentação

Faculdade de Filosofia, Letras e Ciências Humanas da Universidade de São Paulo

Nunes Filho, Wanderley Corino

N972p A poética errante de Orides Fontela / Wanderley Corino Nunes Filho; orientador Ivan Francisco Marques. - São Paulo, 2018.

$80 \mathrm{f}$.

Dissertação (Mestrado) - Faculdade de Filosofia, Letras e Ciências Humanas da Universidade de São Paulo. Departamento de Letras Clássicas e Vernáculas. Área de concentração: Literatura Brasileira.

1. Orides Fontela. 2. Rosácea. 3. Sublime. 4. Impasse. 5. Errância. I. Marques, Ivan Francisco, orient. II. Título. 
NUNES FILHO, Wanderley Corino. A poética errante de Orides Fontela.

Dissertação de mestrado apresentada ao Programa de Pós-graduação em Literatura Brasileira da Faculdade de Filosofia, Letras e Ciências Humanas, da Universidade de São Paulo, como parte dos requisitos para a obtenção do título de Mestre em Letras (Literatura Brasileira).

Aprovado em:

Banca Examinadora

Prof. Dr.: Instituição:

Julgamento: Assinatura:

Prof. Dr.: Instituição:

Julgamento: Assinatura:

Prof. Dr.: Instituição:

Julgamento: Assinatura:

Prof. Dr.: Instituição: Assinatura: 


\section{AGRADECIMENTOS}

À Eurides, por colocar meus pés no chão;

À Mel, por me ensinar a amadurecer brincando de ser criança;

Às minhas irmãs, Luciana e Lilian, pelo afeto que nos une;

À Cecilia e a sua família, por serem uma extensão da minha;

À Helen, por me ajudar a sonhar e nunca estar distante;

Ao Luiz Trabasso, por me lembrar que é necessário rir;

À Gabriela, pelo afeto incondicional;

À Nélidie, pelos abraços sinceros e afetuosos;

Ao John, pelo convívio além dos muros da universidade;

Ao Vinicius Pinho, pela imensa empatia;

Ao Luiz Melques, Caio Cesar e Umberto Neto, pelas boas conversas;

Ao Eduardo Marinho e Mariana Cobuci, pelas parcerias acadêmicas;

À Mariana Carlos e Rafael Tahan, pelas leituras e apontamentos;

À Giuliana Ragusa de Faria, Jaime Ginzburg, Deusa Maria de Souza

Pinheiro Passos, Maria Elisa Cevasco, docentes que durante a graduação serviram de exemplo pela seriedade e entusiasmo com que conduziam suas aulas;

À Viviana Bosi, Augusto Massi, Luisa Destri e Fernando Paixão pelas ricas contribuições durante os exames de qualificação e defesa;

Ao Ivan Marques, orientador desta pesquisa, por ser um interlocutor generoso e atento;

À CAPES, pela bolsa concedida durante boa parte do mestrado. 


\section{RESUMO}

NUNES FILHO, Wanderley Corino. A poética errante de Orides Fontela. Dissertação (Mestrado). Faculdade de Filosofia, Letras e Ciências Humanas, Universidade de São Paulo, 2018.

Este trabalho propõe a leitura do livro Rosácea (1986), de Orides Fontela, com o intuito de verificar seu caráter heterogêneo. A obra em questão é composta por cinco blocos bem definidos como se vê pela nomeação das partes, a saber, "Novos", "Lúdicos", "Bucólicos", "Mitológicos" e "Antigos". Muito embora a poeta justifique que se trata de um livro organizado às pressas, observamos que a multiplicidade temática e temporal dos poemas forma uma espécie de panorama de sua obra. A fim de refletir sobre esse assunto, apresentaremos os aspectos formais do livro. Em seguida, lançaremos nosso olhar para os poemas que tematizam a consciência dos impasses de sua produção poética. Propomos também a leitura de outro grupo de textos que apontam para uma tentativa de inflexão por meio do uso da ironia através da paródia de lugares comuns. Em meio a tais discussões, recuperaremos o conceito de sublime na tradição filosófica, com o intuito de verificar se tal noção pode ser aplicada à poesia oridiana, conforme defende boa parte de sua fortuna crítica.

Palavras-chave: Orides Fontela; Rosácea; sublime; impasse; errância. 


\begin{abstract}
NUNES FILHO, Wanderley Corino. Orides Fontela and the poetic of the erring. Dissertação (Mestrado). Faculdade de Filosofia, Letras e Ciências Humanas, Universidade de São Paulo, 2018.

In the present work I shall analyze Rosácea (1986), by Orides Fontela, in order to verify its heterogeneous aspect. This book is composed by five well-defined sections, as we can see in the way they are named after, namely, "Novos", "Lúdicos", "Bucólicos", "Mitológicos" and "Antigos". Even though Orides Fontela justifies the structure by stating that the book was organized in a rush, we can observe that its thematic and temporal multiplicity creates some sort of panorama of her body of work. With the aim of reflecting on that matter, I must introduce the formal aspects of the book. Then, I will present a selection of poems that thematize the consciousness towards the impasses of her poetic production. I also will introduce another group of poems that indicates an inflection attempt through the use of the irony as they parody some commonplaces. Amidst those discussions, I shall the philosophical concepto of the sublime should be recovered in order to verify if it can be applied to poetry of Orides Fontela, as defend great part of her critical fortune.
\end{abstract}

Keywords: Orides Fontela; Rosácea; sublime; impasse; erring. 


\section{SUMÁRIO}

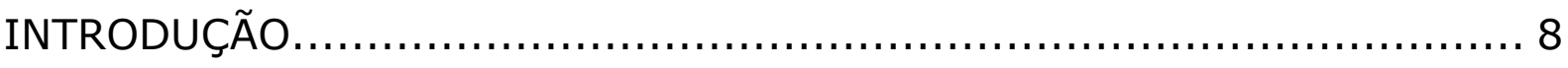

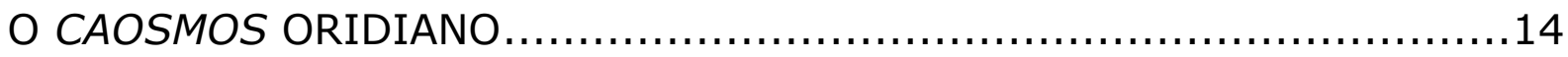

ORIDES FONTELA E A CONSCIÊNCIA TRÁGICA .............................29

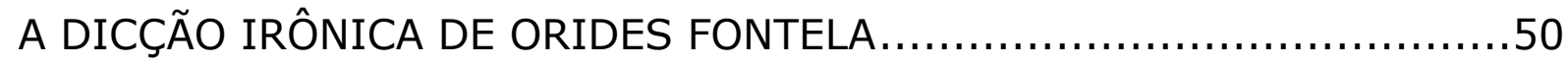

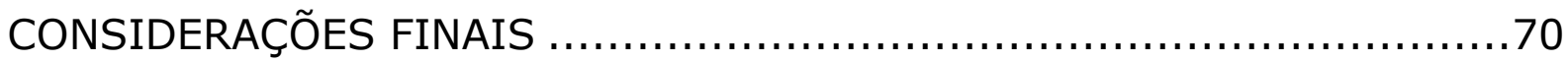

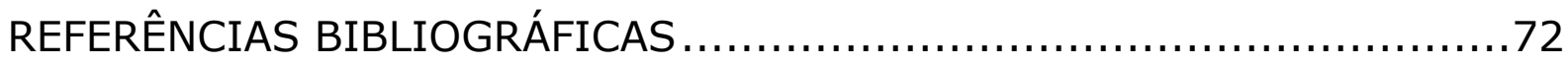




\section{INTRODUÇÃO}

A presente dissertação é o produto de uma pesquisa que sofreu alguns recortes ao longo de sua elaboração. A princípio, a proposta era tratar dos dois últimos livros de Orides Fontela, a saber Rosácea (1986) e Teia (1996), tendo em mente que os estudos existentes privilegiam os pontos de contato que eles possuem com os títulos anteriores, em uma relação hierárquica de dependência. Os apontamentos da banca de qualificação, composta pela Profa. Dra. Viviana Bosi e pelo Prof. Dr. Augusto Massi, nos levaram a repensar 0 projeto de modo a nos concentrar exclusivamente em Rosácea, como uma oportunidade de aprofundar as análises. É preciso mencionar também que esta dissertação amplia os resultados obtidos na pesquisa de Iniciação Cientifica intitulada Rosácea: um possível ponto de inflexão na obra de Orides Fontela, sob a orientação do Prof. Dr. Ivan Francisco Marques.

A dissertação é composta de três capítulos: uma apresentação dos aspectos formais de Rosácea, tomando sua estrutura como ponto de partida para a leitura dos paradoxos tematizados ao longo do livro; uma investigação em torno do conceito do sublime e sua relação com a poética oridiana; e uma observação sobre a apropriação de certos lugares comuns do discurso. Sustentamos a hipótese de que o caráter heterogêneo de Rosácea aponta para uma espécie de percurso da obra oridiana que muito se relaciona aos impasses na constituição de sua diç̧ão poética.

Considerada uma das vozes de maior importância da poesia brasileira contemporânea, Orides Fontela nasceu em São João da Boa Vista em 1940 e faleceu em São Paulo no ano de 1998. Foi 
também aluna do curso de filosofia da Universidade de São Paulo. Sua obra poética é composta de cinco livros de inéditos Transposição (1969), Helianto (1973), Alba (1983), Rosácea (1986) e Teia (1996) -, além de três coletâneas: Trevo (1988), Poesia Reunida (2006) e Poesia Completa (2015), sendo que as duas últimas foram publicadas postumamente ${ }^{1}$.

Sua fortuna crítica conta tanto com prefácios e artigos de jornais e de revistas acadêmicas à época dos lançamentos de seus livros, como ensaios mais longos e dissertações de mestrado mais recentes. Muito embora haja certo consenso de que sua obra gire em torno da busca da palavra indizível e do real, notamos que a classificação da poética oridiana é tarefa difícil. Como observa Davi Arrigucci Jr., há em suas composições "uma profunda experiência incorporada, mas transfigurada em termos abstratos" 2 . Antonio Candido registrou tal singularidade como uma espécie de enigma, em prefácio ao livro Alba:

Um poema de Orides tem o apelo das palavras mágicas que o pós-simbolismo destacou, tem o rigor construtivo dos poetas engenheiros e tem um impacto por assim dizer material de vanguarda recente. Mas não é nenhuma destas coisas, na sua integridade requintada e sobranceira: e sim a solução pessoal que ela encontrou ${ }^{3}$.

Sua categorização de fato é muito difícil, mas o que nos mais interessa é averiguar em que consiste essa "solução pessoal". Num esforço de síntese bastante alinhado à perspectiva de Candido, Alcides Villaça adverte o leitor sobre a necessidade de abrir mão de certos pressupostos ou rótulos, uma vez que "são as etiquetas que

\footnotetext{
1 Vale mencionar que Poesia Completa traz ainda 27 poemas inéditos da autora.

${ }^{2}$ Davi Arrigucci Jr. Na trama dos fios, tessituras poéticas. Depoimento a Cleri Aparecida. Biotto e Laura Fonseca de Almeida. In: Jandira, n², Juiz de Fora, outono de 2005, p. 116.

${ }^{3}$ Antonio Candido. "Prefácio" de Alba. SP: Roswitha Kempf, 1983, p.4.
} 
devem servir aos produtos" ${ }^{4}$. Por meio de uma enumeração negativa, Villaça trata da dificuldade em aplicar réguas à poesia de Orides:

Sem bairrismo, sem regionalismo, sem nacionalismo; à margem de "vanguardas"; imune à parodização como sistema; sem biografismo, sem confessionalismo, sem psicologismo; sem expansão retórica, mas sem minimalismo triunfalista; fora do anedótico, do panfleto, da provocação; sem bandeira política, estética ou ecológica; sem escatologia agressiva, dramatismo ou ressentimento - em que águas, afinal, navega ou lança âncora a poesia sem rótulo de Orides? ${ }^{5}$

Este trecho se configura como um gesto duplo de Villaça frente à obra oridiana, pois o crítico recua para poder avançar: recua na medida em que elenca todas as definições que escapam à obra; avança ao lançar um olhar mais atento às suas características, mesmo que na forma de um questionamento retórico. Em resposta à sua própria interrogação, Villaça aponta que há na poesia oridiana a "liberdade que tem a consciência de retirar das experiências vividas uma suma qualitativa" ${ }^{6}$.

Conforme observaremos nos capítulos adiante, tal liberdade também se relaciona à maneira bastante pessoal com que Orides Fontela se apropria dos silêncios, das imagens poéticas clássicas e dos clichês da linguagem. No que diz respeito ao silêncio, Antonio Candido vê nele um valor positivo, pois sua poética é descrita como uma "parcimoniosa opulência", dada a capacidade de "dizer densamente muita coisa por meio de poucas, quase nenhumas palavras" 7 . Orides lança mão de símbolos pertencentes ao

\footnotetext{
${ }^{4}$ Alcides Villaça. "Símbolo e acontecimento na poesia de Orides". In: Estudos Avançados, no 29.85, 2015, p. 310.

${ }^{5}$ Ibid., p.310.

${ }^{6}$ Ibid., p. 310-311.

7 Antonio Candido. "Orelha" de Trevo. Orides Fontela, 1969 - 1988. São Paulo: Duas Cidades, 1988, não paginado.
} 
repertório da lírica tradicional, sem que, no entanto seus significados tornem-se fixos. É neste sentido que esperamos demonstrar que não é possível sustentar um único modo de leitura que sirva para toda obra oridiana, considerando não só a variação da perspectiva na orbita espiralar dos símbolos, mas também a alternância no enfoque de seus poemas. No caso de Rosácea, nos parece mais produtivo atentar para o modo em que se constrói sua dicção poética, visto que parece haver uma alternância entre 0 trágico e o irônico.

Contudo, conforme mencionamos, é também comum verificar em outros trabalhos o demasiado interesse em destacar a reflexão em torno do inefável como se este fosse o eixo central de toda sua obra. Entre a palavra e o silêncio, tais discussões enveredam por caminhos que privilegiam a abstração da linguagem voltada para si. De maneira um tanto simplista, Vinícius Dantas em "A nova poesia brasileira e a poesia" relaciona a presença do silêncio na produção poética da época a uma espécie de paralisia que conduz "à perda de discernimento e crítica" ${ }^{8}$. Ao comentar a poesia de Orides Fontela, o autor pressupõe que há ali um distanciamento do real, como se seus poemas sugerissem a aceitação "acrítica e demasiado complacente" da transcendência. Para Dantas, a poesia oridiana se constrói tendo como base um falseamento estético estritamente acessório, marcado pelo "pendor para o decorativo". O crítico conclui que o uso de técnicas como o corte da palavra, bem como sua espacialização na página "pouco contribuem para a riqueza de sua poesia e o sentido dela" ${ }^{9}$. Trata-se de um julgamento superficial, pois, como tentaremos demonstrar pelas análises, há o diálogo entre a forma e o conteúdo das composições de Orides Fontela.

8 Vinícius Dantas, "A nova poesia brasileira e a poesia". In: Novos Estudos CEBRAP, n 16 , dezembro de 1986, p. 41.

${ }^{9}$ Ibid., 52. 
Ao afirmar que os poemas de Orides são "reflexivos, impessoais, opacos do sentimento e cegos para as coisas pragmáticas" 10 , Letícia Raimundi Ferreira parte de uma perspectiva semelhante à de Dantas. Contudo, Ferreira modaliza seu discurso quando diz que não se trata de uma forma de alienação. De maneira acertada, a autora ressalva que "a poesia metapoética, como poesia simbólica, centra as atenções sobre si mesma, sem com que isso deixe de constituir-se como instância mediadora entre o eu e o mundo". ${ }^{11}$

Assim sendo, o primeiro capítulo, intitulado "O caosmos oridiano", toma emprestado o neologismo criado por Orides Fontela para explicar a organização de Rosácea. Nossa ideia é olhar para aspectos formais da obra, e mostrar como o título, a epígrafe e a sua divisão em cinco partes constituem elementos produtores de significado. Nossa hipótese é que o livro serve como uma espécie de balanço da obra oridiana, visto que lança o olhar em duas direções aparentemente conflitantes: o passado (poemas da seção "Antigos") e o presente (poemas da seção "Novos"). Interessa-nos verificar se há algum significado por detrás deste duplo movimento.

No capítulo 2, chamado "Orides Fontela e a consciência trágica", investigaremos a noção do sublime com o propósito de identificar traços trágicos na representação de seus poemas, uma vez que há neles a consciência dos impasses. Tendo isso em mente, nos interessa verificar se é possível dizer que há a prevalência de um tom pessimista.

Além da consciência trágica dos obstáculos, observamos que há poemas em Rosácea que são fortemente marcados pela ironia.

\footnotetext{
${ }^{10}$ Letícia Raimundi Ferreira. A lírica dos símbolos de Orides Fontela. Rio Grande do Sul, ASL: Pallotti, 2002, p. 109.

${ }^{11}$ Ibid., p. 110.
} 
Assim sendo, o terceiro capítulo, nomeado "A diç̧ão irônica de Orides Fontela" se voltará para os clichês da sabedoria popular e para os lugares comuns da linguagem com a intenção de analisar os processos de alusão e paródia como possibilidades de ressignificação dos paradigmas. 


\section{O CAOSMOS ORIDIANO}

A tarefa atual da arte é introduzir o caos na ordem. Minima moralia, Theodor W. Adorno ${ }^{12}$

"Coisas novas, fundos de gaveta e restos de memória" ${ }^{13}$, assim define Orides Fontela o livro Rosácea, lançado em 1986. Não houvesse a poeta dado tal definição, ainda assim seríamos capazes de perceber seu caráter heterogêneo, a começar pela divisão do livro em cinco partes, que se apresentam na seguinte ordem: "Novos", "Lúdicos", "Bucólicos", "Mitológicos" e "Antigos".

Uma leitura preliminar nos permite ver que a escolha dos termos que nomeiam cada parte está em conformidade com os textos que as integram. Além da alusão ao despertar de uma nova manhã no poema "Aurora", a seção "Novos" traz a ideia da tentativa de construção de novo percurso, tanto em "Iniciação" como em "Errância", aspecto que aprofundaremos nos capítulos seguintes.

Os poemas identificados como "Lúdicos" propõem jogos, ora de imagens, como em "Habitat" ("O peixe / é a ave / do mar // a ave / o peixe / do $\mathrm{ar}^{\prime \prime}$ ), ora de palavras, a exemplo do trocadilho em "Maya" ("A mente / mente / e o corpo / (ah) / consente."). O caráter lúdico dos textos que compõem esta seção também pode ser observado no uso da paródia que toma como base tanto expressões conhecidas do repertório popular, como se vê em "O anti-César" ("Não vim. / Não vi. / Não havia guerra alguma."),

\footnotetext{
12 "Aufgabe von Kunst heute ist es, Chaos in die Ordnung zu bringen". Theodor W. Adorno. Minima moralia. Frankfurt am Main, Suhrkamp Verlag, 1970, p. 298. tradução nossa.

13 Orides Fontela, "Nas trilhas do trevo", In: MASSI, Augusto (Org.). Artes e ofícios da poesia. 1. ed. Porto Alegre/ São Paulo: Artes e Ofícios/ Secretaria Municipal de Cultura de São Paulo, 1991, p.260.
} 
como em poemas-homenagem que estão compilados em sequência, a saber, "CDA (imitado)", "CDA (relido)", "Homenagens" e "Homenagens II" ${ }^{14}$.

Passando para a seção seguinte, é notório que, em linhas gerais, os poemas arrolados em "Bucólicos" se identificam com o conceito que os une, dada a presença de elementos da natureza. Não só o poema "Bucólica" não só se assemelha ao nome da seção em que está inserido, mas também elege a vaca, em meio ao pasto, como imagem central. Paralelamente, o pássaro aparece em três poemas desse conjunto: "O pássaro inesperado", "Bem-te-vi" e "Jardim". Além disso, "Rosas", "Flor", "Encanto" e, novamente, "Jardim" mobilizam a flor em suas composições. Vale também destacar que o poema "Gatha" toca na relação entre natureza e espiritualidade: "O vento, a chuva, o Sol, o frio / tudo vai e vem, tudo vem e vai. / Tenho a ilusão de estar sonhando. / Tenho o manto de Buda, que é nenhum.".

De maneira semelhante, os títulos dos poemas que compõem "Mitológicos" explicitam as relações que estabelecem com o bloco por meio de referências à tradição oral e literária de origens diversas: "Lenda", "Dom Quixote", "Dragão", "Anti-Gênesis", "Ananke" e "Esfinge". Além destes, Orides Fontela se aproveita de repertórios mitológicos para compor outros poemas, tais como "Rebeca (II)", em referência bíblica, e "Esconjuro", lidando com a matriz greco-romana ao incorporar figuras femininas como Selene, Diana, Perséfone, Medusa, Medéia, Circe, Helena e Hécate.

Quando se olha para a produção poética de Orides Fontela, percebe-se que há no livro Rosácea um procedimento incomum: a nomeação de um grupo de poemas não a partir de uma delimitação

\footnotetext{
${ }^{14}$ Trata-se de releituras não só de poemas de Carlos Drummond de Andrade, mas também textos de outros autores, como Manuel Bandeira, Jean-Jacques Rousseau e Mário Quintana.
} 
temática, mas por meio de uma seleção temporal. Embora os textos dos quatro blocos até agora mencionados não possuam datação, podemos crer na hipótese de que, ao menos a seção "Novos" foi escrita próxima à data de publicação do livro. Já no caso de "Antigos", vemos que ela apresenta poemas da década de 60. Vale observar que a seção "Novos" abre o livro, ao passo que a "Antigos" foi posta no final. Ou seja, a distinção temporal entre os poemas é marcada também pela distância das posições que ocupam na organização da coletânea, sendo que ambas as seções estão postas simetricamente nas extremidades de Rosácea. Há de se ressaltar que boa parte dos poemas em "Antigos" é acompanhada por datação, gesto sem precedentes na obra oridiana e que não se repete no livro Teia ${ }^{15}$.

\begin{tabular}{|l|l|}
\hline Título do poema & $\begin{array}{l}\text { Datação do } \\
\text { poema }\end{array}$ \\
\hline "Origem" & Sem datação \\
\hline "Centro (II)" & Sem datação \\
\hline "Duas odes (antigas)" & Sem datação \\
\hline "Sal" & Sem datação \\
\hline "Botânica" & Sem datação \\
\hline "A paz" & Sem datação \\
\hline "Ceia" & Sem datação \\
\hline "Partilha" & Sem datação \\
\hline $\begin{array}{l}\text { "Soneto à minha irmã (nascida } \\
\text { morta)" }\end{array}$ & $26 / 02 / 1962$ \\
\hline "Alta agonia é ser, difícil prova:" & $25 / 10 / 1963$ \\
\hline
\end{tabular}

${ }^{15}$ Os poemas datados não possuem título, com exceção de "Soneto à minha irmã". Aqui eles serão mencionados, como é de praxe, por meio da reprodução de seus primeiros versos. 


\begin{tabular}{|l|l|}
\hline $\begin{array}{l}\text { "Cansa-me ser. A chaga } \\
\text { inumerável" }\end{array}$ & $23 / 07 / 1964$ \\
\hline "Casa lúcida, habitada" & $01 / 11 / 1964$ \\
\hline $\begin{array}{l}\text { "Olhos vertidos no desamparo } \\
\text { extremo" }\end{array}$ & $04 / 02 / 1965$ \\
\hline "Lentamente ferido" & $20 / 04 / 1965$ \\
\hline $\begin{array}{l}\text { "Os domínios da luz, onde as } \\
\text { potências" }\end{array}$ & $17 / 03 / 1967$ \\
\hline "Inútil a ternura pelo leve" & $04 / 04 / 1967$ \\
\hline $\begin{array}{l}\text { "O branco é campo para o } \\
\text { desespero" }\end{array}$ & $17 / 05 / 1968$ \\
\hline
\end{tabular}

A tabela acima nos permite ter uma dimensão mais clara quanto às datas e ao ritmo de produção dos poemas. Vemos que, a partir de 1962, há uma regularidade quase que anual no intervalo entre os textos até o último, datado de 1968, ano que precede o lançamento de Transposição. É importante lembrar que na década de 1960 Orides Fontela já tinha em mãos material suficiente para a publicação de dois livros; são eles uma versão prototípica de Rosácea - chamada pela poeta de "Rosácea I (o enjeitado)" - e Transposição. Em 1969, porém, só esse último veio a ser publicado, dando início a sua obra poética. Apesar de boa parte destes poemas remontarem à década de 1960, não podemos afirmar categoricamente que todo o bloco "Antigos" pertence de fato ao livro engavetado, visto que não são todas as composições que recebem datação.

De qualquer modo, é preciso observar que os nove textos acompanhados por datas são justamente os que possuem regularidade formal. Enquanto os poemas sem datação não apresentam restrição métrica no que se refere à estruturação dos 
versos, os demais foram escritos na forma fixa do soneto ${ }^{16}$. Se percorrermos toda a obra poética oridiana, veremos que a escrita em sonetos é rara. Um deles, datado de 1968, é o poema "O branco é campo para o desespero":

O branco é campo para o desespero

é quando sem infância persistimos

e nos fita de face a luz sem pausa

da memória suspensa (tempo em branco).

O branco é luz aberta: existimos

sem sombra de segredo, sem mais causa

sem mais infância em nós. É desespero

nos fixando (puro campo branco).

O branco é branco apenas. Sem refúgio

insistimos na luz. A luz constrói

a flor em nós (sua rosácea branca).

O branco é campo para a crueldade

onde nos encontramos: tenso espaço

na luz vivente (branco apenas, branco).

Além do rigor formal dos versos acima, observamos que o raciocínio em torno do branco é construído por meio de uma linguagem abstrata não só por conta do uso da tautologia "O branco é branco apenas", mas também por mobilizar expressões

\footnotetext{
${ }^{16}$ Observamos que a contagem silábica varia de poema a poema: quatro são estruturados em versos decassílabos, a saber, "Soneto à minha irmã (nascida morta)", "Alta agonia é ser, difícil prova:", "Cansa-me ser. A chaga inumerável" e, "Inútil a ternura pelo leve". Já "Casa lúcida, habitada" apresenta versos em redondilha maior, enquanto que "Olhos vertidos no desamparo extremo" traz versos de onze sílabas. Notamos também a presença de sonetos com alguma variação métrica, a exemplo de "Lentamente ferido", composto de versos hexassílabos, mas que se encerra com um verso de quatro sílabas. Por fim, vemos em "Os domínios da luz, onde as potências" semelhante irregularidade métrica ao final do poema. Embora prevaleçam versos decassílabos, o poema fecha com um verso de onze sílabas.
} 
um tanto vagas, como "luz sem pausa", "memória suspensa", "luz aberta", "puro campo branco" e "luz vivente". Tais construções apresentam de um lado o domínio da memória, também representada pela "infância", e de outro o campo da luz, igualmente descrito como "tempo em branco". A discussão do poema é centrada na incompatibilidade entre essas duas dimensões, sendo que a segunda demonstra sua face implacável, qualificada pelos termos "desespero", "sem refúgio" e "crueldade".

Vale apontar que mesmo em Transposição, publicado um ano depois da escrita de "O branco é campo para o desespero", não se encontram sonetos, mesmo se tratando do livro dentro da produção oridiana com menos experimentação formal. Chama a nossa atenção, por exemplo, a brevidade dos versos de "Torres", em oposição ao poema que vimos logo acima:

TORRES

$$
\begin{aligned}
& \text { Construir torres abstratas } \\
& \text { porém a luta é real. Sobre a luta } \\
& \text { nossa visão se constrói. O real } \\
& \text { nos doerá para sempre. }
\end{aligned}
$$

Enquanto o soneto de 1968 apresenta catorze versos decassílabos, a composição de 1969 é mais enxuta não só por se tratar de uma única estrofe de quatro versos, mas também dada a métrica no esquema $7-10-10-7$, onde há o encurtamento dos versos 1 e 4 . É curioso contrastá-lo com o soneto anterior no que se refere ao uso da linguagem. Conforme observa Ivan Marques, "Torres" é composto "sem metáforas, de modo lógico e assertivo" 17 , forma que destoa dos circunlóquios apresentados nos versos de "O branco é campo para o desespero".

${ }^{17}$ Ivan Marques, "A um passo do anti-pássaro: a poesia de Orides Fontela". In: Estudos de literatura brasileira contemporânea. Brasília, UnB. Artigo no prelo, não paginado. 
Em ambos os textos notamos que há a ênfase sobre o olhar do sujeito sobre o mundo o seu, seja no reconhecimento da crueldade do branco ou da dor causada pelo real. Em ambos os casos há o sujeito que olha de maneira consciente para as limitações, havendo, no entanto modulações distintas em cada poema. Vemos que em "Torres" a "luta" é identificada como ação que move o sujeito frente aos obstáculos do real. De maneira menos diligente, em "O branco é campo para o desespero" a resposta do sujeito, diante do sofrimento que o acomete, é quase que unicamente a sua existência, disposição que se percebe nos verbos "persistimos" e "insistimos". Ou seja, apesar da diferença formal relacionada ao uso da métrica nos dois poemas, é notória a aproximação entre eles, pois a ideia de resistência presente nesses verbos se conecta a dimensão da luta apresentada em "Torres". Além disso, há em ambos os textos a recorrência de adjetivos que ajudam na construção de seus paradoxos, o que nos permite averiguar que a particularidade de sua dicção poética é pautada na visão problematizadora das coisas, reconhecida mesmo em um soneto "antigo".

Outro ponto comum aos dois poemas é a apresentação do paradoxo quanto ao uso das imagens. Vemos que há em "Torres" a tensão entre o caráter abstrato da imagem que intitula o poema e a construção da luta que se faz sobre tais torres. Se trata de uma relação de co-dependência entre o poder de abstração, aspecto próprio ao pensamento, e a matéria do vivido. Como destaca Ivan Marques ${ }^{18}$, a operação mental se faz em "Torres" "sem esquecer a base concreta (a experiência) em que ela se assenta". No caso de "O branco é campo para o desespero", temos a polaridade entre a crueldade da luz branca e a resistência do sujeito diante dela, paradoxo que provoca também a construção da "flor branca em

${ }^{18}$ Ibid., não paginado. 
nós", rosácea que se cria na intersecção entre abstração e concretude.

Outro poema de Rosácea que trabalha com a imagem da luz é "Aforismos", que integra o bloco "Novos".

\author{
AFORISMOS \\ Matar o pássaro eterniza \\ o silêncio
}

matar a luz elimina

o limite

matar o amor instaura

a liberdade.

É notória a relação de causa e consequência que se arma ao longo das três estrofes. Transpostas numa relação quase que matemática de sinais, os saldos - a eternização do "silêncio", a eliminação do "limite" e a instauração da "liberdade" - são alcançados mediante a anulação da existência daquelas entidades que os impedem - "o pássaro", "a luz" e "o amor", respectivamente. A segunda estrofe destaca a estreita relação entre a luz e o limite; contudo, não nos parece possível afirmar em que medida o sujeito vê a luz como algo positivo, já que ela é tanto índice de lucidez como de limitação. Observamos uma coerência na maneira como a luz é representada em "O branco é campo para o desespero", visto que o sujeito opta por perseverar apesar do sofrimento - "Sem refúgio / insistimos na luz".

Como vimos anteriormente, a divisão de Rosácea se apoia em dois eixos: o temático (composto pelas seções "Lúdicos", "Bucólicos" e "Mitológicos") e o temporal (onde temos os poemas arrolados em "Novos" e "Antigos"). Não é dado novo na fortuna 
crítica oridiana a afirmação de que as cinco partes de Rosácea aludem às pétalas da imagem da rosa apresentada em seu título ${ }^{19}$. Além disso, a rosácea também é um elemento arquitetônico usado nos tetos e abóbadas das catedrais. Quando a luz solar atravessa a rosácea, o ambiente interno da igreja recebe a iluminação matizada com as cores dos vitrais. Ou seja, a junção desses elementos, que isoladamente possuem características próprias, forma um novo resultado quando realizadas as devidas articulações entre a luz, a rosácea e o interior das catedrais. Tendo isso em mente é que podemos pensar que o título de Rosácea alude à ressignificação das imagens clássicas mobilizadas por Orides Fontela, já que não se trata da utilização de termos com significados cristalizados. Ou seja, em cada poema notamos matizações distintas das imagens adotadas.

Vemos que a despeito do significado que a luz possui em diversas culturas, de modo geral ela representa o conhecimento, 0 bem e a verdade, numa relação antagônica à ignorância, o mal e o engano. Contudo, tanto "O branco é campo para o desespero" como "Aforismos" desestabilizam este binarismo uma vez que a lucidez não é capaz de eliminar o sofrimento. Tragicamente, a dicção oridiana singulariza as imagens que toma emprestada do repertório poético de modo a apresentar seus impasses. Aheterogeneidade formal e temporal, apresentada ao longo das cinco seções de Rosácea nos permite o observar o percurso que a poética oridiana construiu pautada na reflexão crítica em torno da existência e da linguagem poética.

No ano de 1991, em texto intitulado "Nas trilhas do trevo",

19 Utilizando a metáfora das pétalas da rosa, Cleri Aparecida Biotto Bucioli discorre acerca do "entrelaçar de ideias e sentidos, que se enredam não apenas entre as folhas de Rosácea, mas também no conjunto dos livros a compor Trevo.". Cleri Aparecida Biotto Bucioli. Entretecer a tramar uma teia poética: a poesia de Orides Fontela. São Paulo: Annablume: Fapesp, 2003, p. 115. 
Orides Fontela faz um esforço de comentar sua obra poética produzida até então. Neste depoimento, a poeta lança mão de um neologismo para explicar o caráter heterogêneo do livro Rosácea, publicado anos antes:

Justifiquei-me usando como epígrafe um koan de Heráclito, isto é, se o universo é uma bagunça organizada, um 'caosmos', meu livro também poderia ser a mesma coisa, tranquilamente.... ${ }^{20}$.

A invenção desta palavra surge da junção de duas outras, aparentemente conflitantes entre si: "caos" e "cosmos". Contudo, o uso do fragmento 124 de Heráclito no início da obra parece cumprir muito mais do que a função de justificar a organização mal ajeitada dos poemas:

\author{
Coisas varridas e \\ ao acaso \\ mescladas \\ - o mais belo universo.
}

A escolha desta epígrafe antecipa ao leitor a qualidade múltipla dos poemas que encontrará, dada a marcação do plural dessas "coisas", seja pela variedade de repertório imagético ou de tempo de escrita de cada texto. Pensando na antinomia entre os poemas novos e antigos, poderíamos imaginar que o livro pretendesse apresentar uma espécie de evolução dos temas e das formas poéticas no sentido de melhoria. Contudo, tal hipótese não parece se sustentar, uma vez que a ordem das seções não obedece ao tempo cronológico, além de haver uma recorrência temática ao longo da obra. O leitor de Rosácea termina o livro com a impressão de que certos impasses são difíceis (impossíveis?) de serem suplantados, advindo daí a sua recorrência, assunto a ser detidamente analisado no capítulo 2. Por ora, vale dizer que caso a ordem cronológica das seções estivesse mantida ("Antigos" abrindo

${ }^{20}$ Orides Fontela, 1991, loc. cit. 
e "Novos" fechando o livro), a tensão teria sido apaziguada, uma vez que tal linearidade daria margem à interpretação calcada numa ideia de evolução. Ou seja, não nos parece haver uma relação hierárquica entre as partes do livro. Notamos que tais seções se articulam de modo a construir um panorama da poética oridiana, tendo os impasses em torno da construção de sua dicção como espinha dorsal de Rosácea.

O que observamos é que há o retorno de certas questões numa tentativa de virada poética através do uso da ironia, aspecto que veremos com mais vagar no capítulo 3 , mas que também já é prenunciado na epígrafe, pois a estrutura bem rígida de Rosácea contraria à ideia de casualidade da sua organização. Embora a poeta afirme que o livro fora organizado às pressas ${ }^{21}$, vale lembrar que a epígrafe toma emprestado o fragmento de Heráclito que é um koan, gênero textual tradicionalmente capaz de enunciar contradições que vão de encontro ao senso comum. Logo, parece haver um jogo de forças entre os dois polos, caos e ordem, demonstrando que há uma estrutura por detrás da desordem.

O poema "Ceia", inserido no bloco "Antigos" de Rosácea, também parece propor uma conversa entre as partes do livro.

\section{CEIA}

A mesa, todos

interligados

pela realidade do alimento

pelo universo único

do ser

a mesa, todos

coexistem no júbilo

comungando a oferta pura das coisas.

${ }^{21}$ Ibid., 260. 
É visível o uso de palavras que orbitam em torno do cristianismo, visto que foi na Última Ceia, celebrada por Jesus, que seus apóstolos se reuniram em torno da refeição com o intuito de agradecer a Deus. Todavia, para além da aparente relação que o poema trava com a Eucaristia, vemos que há o diálogo subterrâneo com a epígrafe de Rosácea, dada a insistência em termos referentes ao tema da conciliação. Se na epígrafe há a menção às coisas mescladas, tal ideia ressoa em "Ceia" na medida em que a noção de unidade aparece nos trechos "todos / interligados", "universo único" e "todos / coexistem, no júbilo / comungando". Interessante notar que a ideia de unidade também se reflete na estrutura, pois, além de haver apenas um ponto final, todos os versos estão dispostos em uma única estrofe. Também podemos observar no eixo central do poema a ênfase no trecho "universo único / do ser", como se todas as coisas, mesmo que paradoxais, convergissem para essa espécie de núcleo que as unem.

Notamos que a anáfora é aproveitada em "Ceia" de modo a desempenhar uma dupla função. O uso reiterado do trecho "a mesa, todos", nos versos 1 e 6, tem um caráter retórico ao enfatizar a coesão do poema, além de contribuir, por meio do paralelismo, para a uniformidade rítmica do poema. Quanto às duas ocorrências da palavra "todos", vemos que elas se referem inevitavelmente aos apóstolos presentes na Última Ceia. Contudo, é de se pensar que há outra possibilidade de leitura desse termo. De certa forma, o seu caráter impreciso se assemelha ao termo genérico utilizado na epígrafe - "coisas". Em ambos os casos percebemos o eco em relação à estrutura múltipla do livro; logo, a ideia de universo único, já alvitrada no koan emprestado de Heráclito, reaparece em "Ceia", sugerindo uma ideia menos de embate do que de harmonia.

Um aspecto interessante apontado em "Ceia", e que também 
pode ser observado em outros poemas, é uma espécie de tensão entre o significado aparente das imagens mobilizadas e o essencial que se encontra em uma corrente subterrânea, dimensão que críticos como Augusto Massi e Ivan Marques têm procurado valorizar, associando-a a traços de negatividade recorrentes na poesia de Orides Fontela "como a violência, a destrutividade" ${ }^{22}$. É nesse sentido que, no poema "Origem", que abre o bloco "Antigos", o olhar do leitor é conduzido pela constante ação de despojar tudo aquilo que se apresenta como excesso:

\section{ORIGEM}

Nem flor nem folha mas

raiz

absoluta. Amarga.

Nem ramos nem botões. Raiz íntegra. Sórdida.

Nem tronco ou caule. Nem sequer planta - só a raiz é o fruto.

Observamos que o uso do paralelismo sintático construído pela sucessão de negações iniciadas com a conjunção "nem" acaba por definir a imagem por meio das recusas. Essa espécie de construção às avessas diz tanto do objeto descrito quanto da voz que o descreve. As três estrofes expõem um repetitivo movimento marcado pela rejeição das partes da planta que estão na superfície - "flor", "folha", "ramos", "botões", "tronco", "caule" - em detrimento daquilo que está no subterrâneo - "raiz". Tal movimento segue uma estrutura que apresenta os substantivos

\footnotetext{
${ }^{22}$ Trata-se de material ainda inédito concedido por Ivan Marques.
} 
que se referem aos objetos de recusa, para depois detalhar, ao final de cada estrofe, as características da raiz, que equivale no caso à essência do ser. Assim sendo, há nas duas primeiras estrofes a descrição da raiz por meio de adjetivos que podem ser divididos em dois grupos: os que denotam sua superioridade ("absoluta" e "íntegra") e os referentes à sua impureza ("amarga" e "sórdida"). Vale também comentar que a exterioridade da planta, por mais bela que seja, é perecível dada sua existência relativa, em oposição ao caráter absoluto da raiz. A terceira estrofe foge, em parte, desse esquema: a recusa que precede a alusão à raiz, nos versos 6 e 7, é semelhante, apesar da variação - três recusas em vez de duas, como nas estrofes anteriores. Porém, a alteração mais evidente está na ausência de atributos da raiz. Há, na verdade, uma relação de equivalência entre os termos "raiz" e "fruto".

Vale apontar que na segunda estrofe, há um aumento progressivo do recuo em relação à margem esquerda, distância que se mantém nas duas estrofes finais. Este procedimento, somado à extensão mais curta dos últimos versos, cria um efeito visual que resulta na aproximação gradativa em relação ao centro da página. Assim sendo, tal disposição dos versos parece imitar uma "escada", como se, a cada estrofe, o poema descesse mais um degrau em relação à origem/raiz da planta. É na esteira desse pensamento que a acomodação dos versos parece imitar a busca pela essência. Embora haja uma recusa de todos os demais elementos, a raiz é poupada. Isso nos faz pensar que não se trata propriamente de um desejo de destruição da planta e daquilo que ela figura, visto o interesse em dar evidência à sua raiz. Tal gesto demonstra que Orides Fontela pauta seu fazer poético na busca por aquilo que está além da aparência (a flor, o caule e a folha), pelo modo negativo com que dela se despoja desses elementos. A busca pela essência (a raiz) não é, contudo, ingênua ao ponto de crer num estado 
ancestral das imagens que mobiliza; se trata de essência na medida em que as marcas da experiência concreta servem, mesmo que de maneira indireta, como subsídios para tornar pessoais as imagens que toma emprestada. E é por meio desse processo que a negatividade e os impasses se espraiam ao longo da poética oridiana. 


\section{ORIDES FONTELA E A CONSCIÊNCIA TRÁGICA}

(...) liberdade significa escolha e escolha significa possibilidade.

Possibilità e libertà, Nicola Abbagnano ${ }^{23}$

Embora o uso do neologismo caosmos seja válido para qualificar a organização de materiais díspares em Rosácea, dada sua divisão pautada por recortes temáticos e cronológicos, tal denominação não contempla uma série de outras questões que o livro apresenta. Melhor dizendo, a aparente desordem na estrutura de Rosácea parece ser mais do que um aspecto formal, uma vez que adensa, de maneira programática, tensões já trabalhadas nos livros anteriores. Isso se vê tanto na aproximação dos termos a priori conflitantes (caos e cosmo), como na inversão da linearidade temporal que agrupa os poemas. Ao que nos parece, os diversos impasses tematizados ao longo da obra de Orides Fontela - em torno da linguagem, do fazer poético, da busca por uma diç̧ão própria - são postos em evidência dado o caráter panorâmico deste livro.

Talvez um dos primeiros impasses que tenha se apresentado a Orides Fontela foi o da construção de uma voz poética no que se refere ao modo de fazer poesia. A intenção de não ser vista como poeta de dicção pessoal e intimista fez com que seus poemas acabassem se tornando bastante simbólicos. Em certo sentido, a recusa de uma poética centrada na expressão do eu anda em paralelo à "busca de uma verdade essencial" ${ }^{24}$, como se vê na depuração das imagens poéticas que são mobilizadas ao longo de sua obra. Tal esforço de abstração muito se relaciona com o fato de que Orides tentou evitar que seus versos fossem qualificados como

23 "(...) libertà significa scelta e scelta significa possibilità." Nicola Abbagnano. Possibilità e libertà. Torino: Taylor Torino, 1956, p. 111, tradução nossa.

24 Davi Arrigucci Jr, 2005, p. 119. 
"poesia feminina". Além de ser um rótulo ineficaz, pois nada nos diz quanto ao seu conteúdo, tal nomenclatura reforça um estereótipo de poesia confessional, vista como de qualidade inferior. Como se vê no depoimento a seguir, a preocupação em torno da formação da identidade poética já estava na gênese de seus primeiros poemas:

Eu já era feminista e sabia que minha poesia ia ser desvalorizada se parecesse "poesia de mulher". Daí abstraí e abstraí. Foi uma força: fui aceita. Mas foi, também, uma armadilha, pois assim é que caí na poesia hiper-sublimada, tão própria das mulheres. Tentei me salvar disso nos últimos livros, e inda [sic] tento. ${ }^{25}$

Antes de seguirmos pelos desdobramentos apontados neste depoimento, vale a pena atentarmos para o fato de que o esforço em realizar uma voz poética esteve muito centrado no apagamento de elementos que porventura fossem lidos como da ordem do feminino. Ou seja, há aí um gesto ambivalente, já que o princípio de construção está intrinsicamente ligado a um movimento de recusa. É, aliás, por meio de reiteradas negativas em torno de representações do feminino que é construído o poema "Esconjuro", que integra a seção "Mitológicos" do livro Rosácea:

ESCONJURO

Vai-te, Selene, vai-te daqui

vampira

Diana estéril selvagem

assassina

vai-te, vai-te daqui, noiva do Hades

Perséfone

vai-te caveira pedra morta

Medusa

${ }^{25}$ Orides Fontela, 1991, p. 258. 


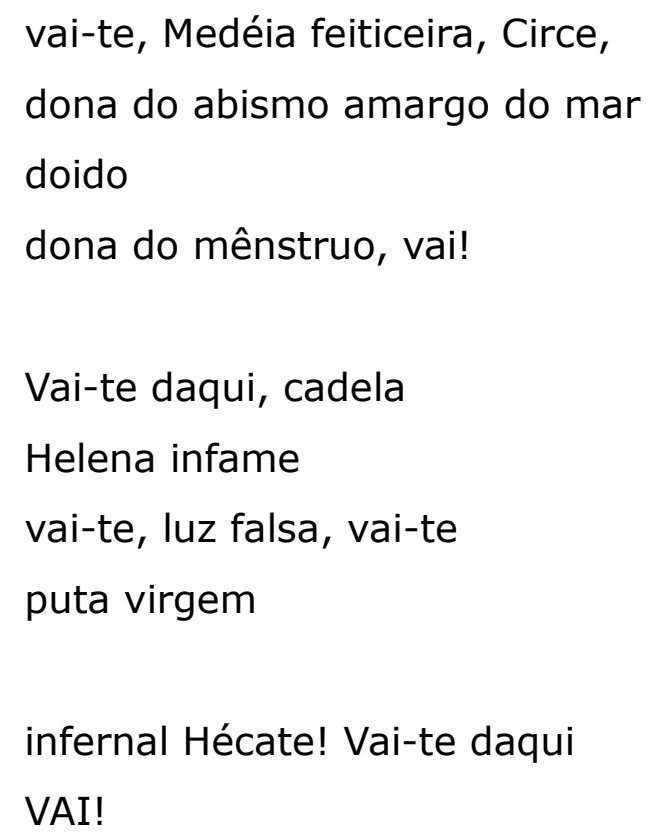

Vemos que o poema faz menção a oito personagens da mitologia greco-romana e que todas elas recebem qualificativos depreciativos que se referem às suas características intrínsecas. Por exemplo, ao descrevê-la como vampira, o poema se aproveita do episódio em que Selene teria concedido a imortalidade a Endímion ${ }^{26}$, o que lhe fez cair em sono eterno. No caso de Diana, o poema joga luz ao fato dela ser uma divindade casta que habita e protege os bosques com suas fulminantes flechas. Já quanto às duas figuras apresentadas na segunda estrofe, elas são descritas de modo a enfatizar sua relação com a morte: Perséfone habita boa parte do tempo o submundo e Medusa causa a morte de quem Ihe encarar. Além disso, há na terceira estrofe a menção à Medéia e à Circe visto que ambas são conhecidas por fazerem uso da magia como forma de ludibriar suas vítimas. Ao mencionar Helena, o poema a descreve como desprezível por ter sido a semente da guerra de Tróia. A última estrofe de "Esconjuro" menciona Hécate talvez pelo fato de que ela é descrita na mitologia grega como uma divindade habitante do Hades, dona de três faces (a virgem, a mãe

${ }^{26}$ Joel Schmidt. Dicionário de mitologia grega e romana. Lisboa: Edições 70, 1994, passim. 
e a velha senhora) e conhecida tanto pelo dom da profecia, quanto por carregar, em uma das mãos, uma tocha que ilumina 0 caminho. Assim sendo, o uso reiterado do imperativo "vai-te" realça o desprezo por tais características (torpor, pureza, morte como dissolução, desprezo pela beleza e luz enganadora). Conforme a leitura proposta por Cleri Aparecida Biotto Bucioli, tais enunciações se relacionam à ideia de desconstrução poética. Segundo a autora, tal destruição é ambivalente na medida em que reconstrói a linguagem original, a saber, a poesia. ${ }^{27}$ No entanto, vale acrescentar que a violência com a qual são tratadas as personagens não está somente em diálogo com o caráter reflexivo da escrita. É preciso assinalar que há no poema um movimento de aproximação entre o que há de negativo nessas figuras do imaginário mitológico e uma suposta estética de escrita feminina. Haveria então na fatura do poema um desejo de expurgar qualquer tentativa de aproximação com a assim chamada "poesia feminina", nomenclatura que mais desclassifica uma produção poética, dados os pressupostos em volta do termo, do que se constitui como uma identidade estética. Em outras palavras, no que se refere à dinâmica entre forma e conteúdo, "Esconjuro" demonstra a ambivalência da construção da voz poética oridiana.

Retornando ao depoimento de Orides Fontela sobre a necessidade de não adotar um tom intimista, a poeta reconhece que o processo de elaboração das imagens se tornou, ao mesmo tempo, solução e armadilha. Por um lado houve a habilidade de mobilizar imagens que condensassem de maneira lúcida "os conteúdos da vivência imediata" ${ }^{28}$; por outro, tal capacidade de depurar as imagens resultou no uso de uma linguagem simbólica, metafórica e um tanto mística, da qual Orides diz tentar se salvar.

${ }^{27}$ Cf. Cleri Aparecida Biotto Bucioli, 2003, p. 125.

${ }^{28}$ Davi Arrigucci Jr. 2005, p. 116. 
O encantamento simbólico na poética oridiana deve ser relativizado, pois o repertório imagético do qual ela lança mão é trabalhado com rigor formal. Parece haver uma espécie de incômodo na fatura de seus poemas, pois a brevidade e o corte dos versos desestabilizam as imagens tradicionalmente elevadas ${ }^{29}$. Tais aspectos formais aparecem em "O espelho", que compõe "Novos".

\section{O ESPELHO}

O espelho: atra

vés

de seu líquido nada

me des

dobro.

Ser quem me
olha
e olhar seus
olhos
nada de
nada
duplo
mistério.

Não amo

o espelho: temo-o.

\footnotetext{
${ }^{29}$ Sobre o assunto, Ricardo Lísias comenta: "Houve quem lesse a disposição por espalhar esses termos como certa queda pelo simbólico, que denunciaria predisposição da poetisa pelo sublime. Não há, em todo caso, nenhum tipo de simbologia oculta na poesia de Orides Fontela e muito menos qualquer tentativa de alcançar algo elevado: ao contrário, o procedimento formal do corte, adotado em conjunto com termos extraídos do vocabulário da natureza, cuja primeira impressão seria a de um fôlego maior, como a fonte que escorre ou o pássaro que voa, de imediato prenuncia a construção do incômodo." Ricardo Lísias. Intervenções: álbum de crítica. São Paulo: Geléia Real, 2014, não paginado.
} 
Se por si só a imagem do espelho antecipa uma discussão sobre a identidade, tanto a cisão dos versos como a divisão estrófica parecem modular tal imagem, de modo que se constrói uma reflexão mais densa sobre a identidade a partir da linguagem. Observamos que o sujeito lírico do poema, ao se colocar frente ao espelho, se dispõe a meditar sobre si próprio. E mais do que se prostrar diante de seu reflexo, há um movimento de travessia pelo objeto com o intuito de melhor compreendê-lo. Devemos chamar a atenção para o fato de que esse objeto é o próprio sujeito poético que, dada a tentativa de distanciamento crítico, se cinde durante essa jornada interior: "me des/dobro". Todavia, a efetividade do distanciamento é difícil de ser averiguada por conta da particularidade do objeto que se intenciona analisar. Vale apontar que isso aparece inclusive na construção do poema, como se vê na segunda estrofe devida a dupla possibilidade de leitura da palavra "ser". Por um lado, podemos entendê-la como substantivo, cujo referente é a identidade do sujeito em terceira pessoa, distanciada. Por outro lado, é também válida a alternativa deste termo se referir ao verbo no infinitivo, cujo agente é a primeira pessoa do poema; assim, o olhar deste sujeito se volta a si próprio, encolhendo o espaço entre ele e o objeto. Em outros termos, há aí a diminuição da distância analítica que se quer objetiva. De todo modo, a oposição entre essas duas leituras não resulta na vantagem de uma sobre a outra. É mais interessante notar a síntese obtida na última estrofe do poema, pois o saldo dessa análise é a consciência de um "duplo mistério".

Muito embora só a última estrofe nomeie a sensação de temor, tal disposição também se apresenta no restante do poema. Podemos até pensar que essa inquietação resulta da cisão entre o ser, objeto de análise, e o ser que o analisa. O receio que a figura do espelho desperta já está na primeira estrofe conforme o caráter 
problemático do nada que se apresenta diante do sujeito. Como quem toma consciência desse vazio como um problema, o sujeito, além de não contemplar tal imagem, desconfia dela, tal qual um anti-Narciso. Só então é que, num movimento duplo de travessia e introspecção, o sujeito se empenha contra o alheamento, uma vez que o verbo "desdobrar-se" também abrange a ideia de "esforçarse ao máximo", para além da que apontamos anteriormente.

Independentemente da imagem mobilizada e do que ela representa, o que salta aos olhos é a postura cautelosa que 0 sujeito assume diante dela. A tentativa de distanciamento que se apresenta em "O espelho" ecoa nas três estrofes do poema "Lembretes", também incluso na seção "Novos":

\title{
LEMBRETES
}

\author{
É importante acordar \\ a tempo \\ é importante penetrar \\ o tempo
}

é importante vigiar

o desabrochar do destino.

Se em "O espelho" a fala em primeira pessoa relata um processo de descrição e análise da imagem que dá nome ao poema, em "Lembretes" o discurso sumariza as experiências em breves asserções de modo que elas servem para recuperar a memória, como se vê na escolha do título. Em tempo, talvez se trate da possibilidade não se recuperar a memória, mas de sua resistência. No entanto, não podemos ignorar que tais lembretes também possuem um tom didático, como se o sujeito do poema estabelecesse um diálogo, seja com o leitor ou consigo próprio, por 
conta das advertências indicadas através das repetições do verbo "ser". Ou seja, aquilo que a memória foi capaz de reter é conscientemente reelaborado por meio de uma fala estruturada, gesto que demonstra certa disposição de abertura ou desejo de comunicabilidade. $O$ uso da anáfora nos versos 1,3 e 5 enfatiza 0 que há de relevante e essencial nas ações que apresenta ("acordar", "penetrar" e "vigiar"). Vale sublinhar que tais verbos estão ligados, numa espécie de gradação, a uma rigorosa atenção. É nesse sentido que a advertência da primeira estrofe trata da necessidade de "acordar / a tempo". Seja por meio de um conselho ou de uma ordem, o poema sugere haver a necessidade de escapar de algo iminente através do despertar da consciência. Muito embora desperte uma apreensão no sujeito, tal objeto não é posto às claras, em virtude do caráter elíptico do poema. No entanto, se trata da mesma precaução que vemos na forma do temor em "O espelho".

Outro aspecto que aproxima os dois poemas se refere ao fato de que há o imperativo de se entranhar no objeto como forma de melhor compreendê-lo, tal qual apresentado na segunda estrofe. Ou seja, esse "penetrar / o tempo" é mais do que uma mera sugestão feita pelo poema. A ênfase recai sobre o modo como esse processo de análise se dá, onde o sujeito atravessa o objeto com o intuito de interpretá-lo. Vale destacar que não é o sujeito que, de maneira passiva, é absorvido pelo tempo, mas o sujeito que opta, dada a necessidade que se impõe, por penetrá-lo. Em outras palavras, a escolha verbal destaca o esforço empregado como condição do processo de autoconhecimento, conforme apresentado no poema anterior. Mas fica a questão: ao que se refere a cautela apresentada em "Lembretes"? Considerando os impasses da construção de uma identidade poética em Orides Fontela, qual poderia ser a natureza dessa ameaça? Vemos que o poema adverte 
a respeito da necessidade de "vigiar / o desabrochar do destino", num gesto de zelo e precaução. Seria legítimo ler esse estado de alerta como um esforço em sintetizar, por meio dos breves lembretes, o impasse com que Orides se deparou em relação à sua escrita? Ao insistir numa postura vigilante, "Lembretes" parece apontar que trabalho depurado da linguagem pode vir a ser tanto solução como armadilha, a qual mencionamos anteriormente, já que o efeito de encantamento do poema (seja pela escolha das imagens clássicas ou pela construção sonora) se sobressai em relação à discussão elaborada no substrato do poema. É nesse sentido que o poema aconselha insistentemente a máxima atenção, pois ao voltar-se para si mesma a palavra poética revela o quão tênue é a linha entre um discurso consciente e um afastado do real. Isto é, se o poema propõe uma reflexão sobre (e por meio da) linguagem, duas são as possibilidades de leitura: ou o poema é mera construção decorativa ${ }^{30}$ e esvaziada de sentido ou há nele uma discussão implícita sobre qual é a sua voz poética ${ }^{31}$.

No entanto, vale retomar a discussão apresentada por Paul Valéry sobre a inutilidade da separação entre linguagem poética e trabalho intelectual. Segundo Valéry, "todos os poetas verdadeiros são necessariamente críticos de primeira ordem"32 na medida em que o poema não se constitui apenas pela presença do universo poético. Observa o autor que o trabalho com a palavra envolve uma série de procedimentos não só de reflexão, mas de ordem prática, pois cabem ao poeta as decisões que possibilitam a construção do poema. Mas como essa relação entre poesia e

\footnotetext{
${ }^{30}$ Cf. Vinícius Dantas, 1986, loc. cit.

31 Seleciono uma passagem importante do comentário feito por Antonio Candido: "Orides Fontela progride de livro para livro com uma firmeza que eu chamaria triunfal, se não fosse tecida de dúvidas, tacteios, discussão implícita no subsolo dos poemas, muitos dos quais não são apenas construção de poesia, mas também um questionamento do fazer poético". Antonio Candido, 1983, p.3.

32 Paul Valéry. Poesia e pensamento abstrato. In Variedades Org. João Alexandre Barbosa. São Paulo: Iluminuras, 1991, p. 216.
} 
pensamento abstrato se apresenta na obra de Orides Fontela? Ao que nos parece, há uma serie de procedimentos que particularizam as imagens clássicas. É na esteira desse pensamento que nosso olhar se voltará para "Águas", incluso na seção "Novos".

ÁGUAS

amargas
cobrem o
barco

as águas

salobras

trazem

o dilúvio, o naufrágio, o necessário

batismo.

Através do

silêncio

cai a

água

filtra-se

através do ser

a inextinguível

água

do silêncio.

Antes de qualquer coisa, é necessário comentar que a forma do poema espelha a qualidade fluida da imagem nele apresentada, demo do que a maleabilidade se apresenta tanto no plano estético como no temático, graças à propriedade amorfa da água. Por conta 
do aspecto visual mais imediato, notamos um efeito de dispersão na página, dado o largo uso de enjambements que imita a liquidez da água. Isso é importante na medida em que o sentido do poema está atrelado a cada verso de maneira individual.

Ainda considerando a estrutura do poema, é nítida a presença de dois grandes momentos que são delimitados não só pela parca pontuação, mas também pelo grande espaçamento inserido entre as estrofes 2 e 3.0 primeiro momento (estrofes 1 e 2) seria marcado pela abundância do elemento aquático, criando uma espécie de alagamento. Tamanha abundância se vê não só pelo fato de que tais águas cobrem o barco, mas também pela menção ao "dilúvio" no oitavo verso ${ }^{33}$. Inclusive, vale apontar que é esse verso o mais longo do poema. Vemos que a primeira estrofe possui quatro versos bem curtos e ritmados, característica que se repete até o terceiro da estrofe seguinte. Se até o momento havia certo espelhamento entre uma estrofe e outra, o verso 8 provoca a quebra da expectativa da regularidade sonora. $O$ seu prolongamento coincide com o momento do poema onde a enchente é apresentada. Outro aspecto sonoro que reforça a ideia de alagamento é fato de que há uma reiteração do ditongo "io" ao fim das três palavras - "dilúvio", "naufrágio" e "necessário. Por outro lado, o segundo momento do poema (estrofes 3 e 4) se opõe ao anterior pois, ao apresentar o escoamento pós-diluvial, constrói a noção de míngua. É interessante notar que no primeiro bloco do poema as duas ocorrências da imagem da água aparecem no plural, reforçando a ideia de abundância, enquanto que na segunda parte o termo é usada no singular, alinhado à ideia de retenção.

Percebe-se que o poema trabalha com o tema do batismo tanto no nível da linguagem quanto no plano conceitual. Em

\footnotetext{
${ }^{33}$ Em nossa contagem, a passagem "o dilúvio, o naufrágio, o necessário" é vista como o oitavo verso. Estamos considerando o título como o primeiro, dada a importância que ele ocupa na leitura do poema.
} 
primeiro lugar, da forma do poema se extrai a ideia de depuração, que é arquitetada através do uso comedido das palavras e dos versos breves. Aliás, tal comedimento está intimamente ligado ao silêncio, seja pela construção lacunar do poema ou ainda por meio do emprego da palavra "silêncio" nos versos 11 e 18. Nesse sentido, tais elementos acentuam a depuração por meio da linguagem. Em segundo lugar, o poema "Águas" remete conceitualmente ao batismo por se tratar de um rito tradicionalmente conhecido por eliminar qualquer indício de contaminação. No entanto, é preciso destacar que o poema particulariza tal cerimônia de purificação. Vemos que, muito embora haja na última estrofe o filtramento da água, tal procedimento não é tão simples e puro quanto se poderia, a priori, imaginar. Dois são os indícios que apontam para a complexidade desse rito batismal. Antes de qualquer coisa, vemos nas primeiras estrofes a referência à qualidade repugnante da água utilizada no batismo, pois se tratam de águas salobras e amargas. Ou seja, a impureza contida na água é componente essencial à iniciação. A tradição religiosa visa eliminar as impurezas e os pecados por meio do batismo, mas o poema parece se aproveitar desta simbologia de um modo bem particular, pois, como vemos em sua segunda parte, a qualidade impura da água não é extinta. Muito embora o poema apresente o esforço em decantar as águas, precisamos olhar com atenção para tal procedimento. Embora não seja feita nenhuma menção à origem destas águas amargas, cabe mencionar que tanto o suor quanto as lágrimas são líquidos da experiência humana que possuem características muito semelhantes. A despeito da relevância desta observação, vemos na última estrofe que tais águas não poderiam sair imaculadas deste processo de decantação, uma vez que serão filtradas "através do ser", que nada mais é que um ente perpassado por experiências. Na verdade, a depuração aqui se liga menos à ideia de limpeza do que ao processo de 
adensamento das experiências. Melhor dizendo, as experiências vividas pelo ser se constituem como algo que não se busca limpar, o que permite ver aí um caráter dúbio de contaminação e pureza.

Dito isso, talvez fique um pouco mais clara a relação de dependência entre o pensamento crítico e a linguagem poética, visto que aspectos como a sonoridade e a disposição gráfica dos versos não são meros acessórios. Longe de serem decorativos, tais elementos são tão relevantes quanto os argumentos desenvolvidos na poética de Orides Fontela, pois eles consolidam um dos temas centrais de sua obra, que é a busca pela essência das coisas. No poema que acabamos de analisar, a água se apresenta como uma imagem desinflada, despida de seu sentido clássico e particularizada. A ideia de purificação é menos significativa para o poema, na medida em que o batizado simboliza, de maneira mais importante, o gesto de dar início a uma nova vida, o que em certa medida se liga ao impasse da poética oridiana.

Por conta do caráter heterogêneo da estrutura de Rosácea, é possível ver que o impasse é tematizado de maneira variada. Ao colocar no mesmo livro poemas da década de 1960 ao lado de outros mais atuais, notamos o recorte diacrônico sobre os obstáculos de sua obra. Tal organização em retrospecto não só analisa o impasse, mas também demonstra a necessidade de tentar superá-lo. Dessa forma, é necessário apontar a coesão entre as partes, dado o poder de síntese da dicção oridiana. Isto se refere não só aos diálogos que os poemas estabelecem entre si, mas também, como apontado no capítulo anterior, à lógica interna que rege Rosácea. Os textos agrupados em "Novos", além de se sustentarem individualmente, apresentam uma espécie de súmula poética quando lidos em conjunto. Muito embora não saibamos a data em que os poemas deste bloco foram de fato escritos, é significativo que composições como "Águas" e "Iniciação" estejam nessa mesma seção. Mais do que a proximidade em datação, esses 
dois poemas apontam para o tema da renovação.

\section{INICIAÇÃO}

Se vens a uma terra estranha

curva-te

se este lugar é esquisito

curva-te

se o dia é todo estranheza

submete-te

- és infinitamente mais estranho.

O poema apresenta frases imperativas condicionadas às orações que as precedem ao longo das três primeiras estrofes, onde vemos que o sujeito se encontra em um cenário hostil. 0 verso final, por estar isolado dos demais, possui um caráter de síntese. Observamos que tal síntese é um tanto quanto negativa, pois inverte a lógica apresentada até então. Podemos afirmar que se trata de um procedimento ambivalente, pois indica "ao mesmo tempo decorrência e negação das hipóteses anteriores" ${ }^{34}$. Aliás, é possível notar que o tom aparentemente agressivo do poema pode ser relativizado, pois os verbos, no modo imperativo, podem indicar tanto ordens como conselhos. De um lado, o discurso parece revelar hostilidade; de outro, o poema apresenta uma advertência marcada por "aquela humildade sábia de quem atenta para o próprio labirinto antes de acusar a tortuosidade alheia" 35 , conforme observa Alcides Villaça.

De todo modo, parece ser legítimo a possibilidade de o

${ }^{34}$ Trata-se de material ainda inédito concedido por Ivan Marques.

${ }^{35}$ Alcides Villaça, 2015, p. 306. 
sujeito se angustiar diante das adversidades do mundo. Mas tomado por essa sensação de angústia, qual seria sua disposição, uma vez que sua existência é limitada pelos obstáculos que a vida apresenta? De acordo com o conceito heideggeriano de angústia, é diante dos impasses que se impõem sobre o sujeito que ele pode reconhece tais impossibilidades não como uma força limitadora, mas como um ato de liberdade. Frente aos obstáculos o sujeito que eventualmente procuraria a transcendência passa a ver angústia como compreensão existencial que "possibilita ao homem transformar a necessidade em virtude: aceitar como um ato de escolha a situação de fato, que é o destino" ${ }^{36}$.

Esse ato de liberdade se configura no poema como o reajuste no modo como o sujeito olha o seu redor. O poema inverte a perspectiva quando declara que o "tu" é tão (ou mais) estranho que o espaço que o rodeia. Tal adequação do olhar lançado às coisas permite recriá-las, o que é semelhante à ideia de Ferdinand de Saussure de que o ponto de vista cria o objeto ${ }^{37}$. De maneira trágica, o ser se reconhece no assombro do mundo. Vale apontar que, ao anuir o impasse, o sujeito não se encontra numa situação de impotência ${ }^{38}$. Há na aceitação de sua condição limitada não só a agência do sujeito que se opõe à passividade, mas também a indicação da necessidade de mudar o modo com que se relaciona com o mundo. De certo modo, tal postura se assemelha à ideia de batismo elaborada ao longo do poema "Águas", pois ambas as composições apontam para o recomeço como uma necessidade,

\footnotetext{
36 Tomo emprestada a explicação formulada por Martin Heidegger do termo "angústia", apresentada por Nicola Abbagnano, Dicionário de filosofia. São Paulo: Martins Fontes, 2007, p. 61.

37 Cf. Ferdinand de Saussure. Curso de Linguística Geral. Cultrix: São Paulo, 1975, p. 15.

${ }^{38}$ Nicola Abbagnano comenta que, diferentemente de Heidegger, Freud vê a angústia não como possibilidade de escolha consciente, mas como "reação do Ego ao perigo", ao qual o sujeito se sente impotente diante da situação presente por remeter a "um acontecimento traumático já vivido". Nicola Abbagnano, 2007, loc. cit.
} 
apesar de reconhecer os limites dessa empreitada. Esse ensejo de reabertura diante do impasse é tematizado em "Iniciação" ao se concentrar no reconhecimento das possibilidades reais da existência, ao passo que "Águas" tematiza, por meio da imagem das "águas salobras" que constitui o "necessário batismo", a ambivalência desse gesto oscilante entre permanência e renovação.

Como apontou Roberta Gonçalves ${ }^{39}$, há na poética oridiana uma constante remissão à Ananke, deusa da inevitabilidade na mitologia grega, símbolo que a filosofia toma emprestado para elaborar o conceito de destino. Comenta a autora que a presença da ananke é fundamental em Rosácea, visto que o peso do Destino se impõe sobre o sujeito. Como vimos em "Iniciação", a terra estranha demonstra que a parcela de mistério do Destino se refere, tanto ou mais, à nossa incapacidade de apreendê-lo. Assim, tal enigma não se separa da nossa condição humana; aliás, o próprio poema opera nessa chave, pois reverte a lógica apresentada - és infinitamente mais estranho -, diminuindo assim a engessada distância entre sujeito e objeto. De todo modo, o sujeito expressa seu temor diante dessa inevitabilidade, seja ela figurada na estranheza do mundo e do próprio sujeito, seja por meio do enigma representado em "O espelho": "Não amo / o espelho: temo-o". Cabe, no entanto, nos perguntar se a poética oridiana traz alguma discussão para além do reconhecimento dos impasses. Por exemplo, poderia o sujeito se sentir frustrado por conta dos obstáculos? Considerando que a frustração não se manifesta em relação a determinado objeto ou circunstância de maneira isolada, por estar intrinsicamente ligada a uma possibilidade de

${ }^{39}$ Cf. Roberta Andressa Villa Gonçalves. Entre a Potência e a Impossibilidade: um estudo da poética de Orides Fontela. Dissertação de mestrado apresentada ao Programa de Pós-Graduação em Literatura Brasileira do Departamento de Letras Clássicas e Vernáculas, FFLCH, USP, 2014, p. 105. 
autofrustração ${ }^{40}$, vale reelaborarmos a questão: a poética oridiana, ao tematizar seus impasses, estaria marcada pela completa desilusão?

Alcides Villaça comenta que há na poesia de Orides Fontela o reconhecimento fatalista, pois o sujeito se pacifica diante da implacabilidade do Destino, gesto que o crítico considera como revelação de um prazeroso estoicismo ${ }^{41}$. Por outro lado, Ivan Marques identifica a presença de um sujeito desencantado diante do seu desajuste em relação ao mundo, cujo discurso reflete uma "visão pessimista e irônica" ${ }^{42}$. Embora essas duas leituras sejam conflitantes em um primeiro momento, cremos ser possível encontrar um meio termo entre elas. Retomando o já mencionado conceito heideggeriano de angústia, o sujeito aceita o Destino não como resignação, mas como escolha. A aceitação parte da ideia de que possibilidades são ofertadas e que o sujeito dispõe da sua liberdade de escolha para se autodeterminar ${ }^{43}$, mesmo que por meio do reconhecimento dos seus limites. Interessante notar que a noção de inevitabilidade do Destino também pode ser lida na chave das imposições externas a que se refere Friedrich Schiller, ao tratar do verbo müssen, que expressa obrigatoriedade em alemão. Schiller arma a oposição entre o Destino e a Vontade (Wille, substantivo referente ao verbo wollen), pois a vontade nada mais é do que a instância que nos permite, de maneira consciente, "seguir ou não uma inclinação ou uma necessidade externa" ${ }^{44}$. $O$ ajuste de perspectiva nos permite então desconfiar, em parte, da afirmação

40 Jean Laplanche. A angústia. São Paulo: Martins Fontes, 1987, não paginado.

${ }^{41}$ Alcides Villaça, 2015, p. 303.

${ }^{42}$ Trata-se de material ainda inédito concedido por Ivan Marques.

${ }^{43}$ Sobre o conceito da liberdade, Nicola Abbagnano afirma que ela se trata de "uma questão de medida, de condições e de limites". Ou seja, se trata de uma liberdade relativa, pois as possibilidades de escolhas do sujeito estão atreladas aos limites que a determina. Nicola Abbagnano, 2007, p. 612.

${ }^{44}$ Pedro Süssekind, "Schiller e a atualidade do sublime". In: Friedrich Schiller: do sublime ao trágico. Belo Horizonte: Autêntica Editora, 2011, p. 95. 
de que a poética oridiana seja marcada por uma dicção estoica. Além disso, o caráter diligente dos poemas até então analisados não corresponde completamente a essa ideia de resignação, a exemplo do discurso autoritário em "Esconjuro" e do olhar analítico do sujeito de "O espelho". Mesmo em poemas onde há o predomínio do pensamento abstrato, a reflexividade está bem mais ligada à cautela do que à alienação, tanto no gesto aconselhador de "Lembretes" e de "Iniciação", como na busca pelo essencial tematizada ao longo dos versos de "Águas". Em outras palavras, a consciência dos impasses não desperta o completo desencanto, mesmo em uma obra fortemente marcada pelo negativo, como é o caso de Rosácea. Em alguma medida, os poemas refletem a cautela em face dos impasses sem que necessariamente eles inibam o sujeito de agir ${ }^{45}$. Tomemos como exemplo o poema "Coruja", presente na seção "Novos", do livro Rosácea:

CORUJA

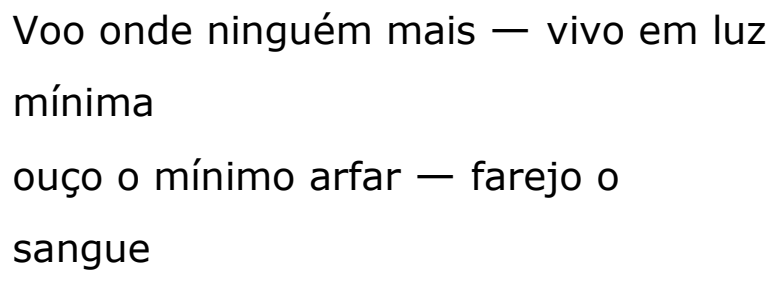

Vemos que a coruja é a imagem central não só por intitular o poema, mas também porque as ações descritas se relacionam a este animal. Em primeira instância poderíamos relacionar a coruja à imagem do pássaro, que na tradição clássica inspira elevação. Porém, essa associação imediata também se mostra insuficiente na

45 Quando aqui tratamos de agência ou alienação, não estamos de modo algum nos referindo à poesia engajada. 
medida em que não dá conta da carga semântica que transita no diálogo entre o poema e a figura que o nomeia. Animal noturno, a coruja é uma ave de rapina cuja extrema concentração lhe dá a vantagem de apreender o ambiente que a rodeia. No poema, a coruja se torna metáfora do sujeito que carece de atenção para realizar o trabalho poético. Vemos que sua autonomia já é anunciada no primeiro verso: "Voo onde ninguém mais".

Queremos destacar que os versos que abrem e fecham o poema constroem uma moldura temático-estrutural pautada pela escuridão que caracteriza o momento da caça da ave - "luz mínima" e "pleno escuro". Estes trechos, pertencentes ao plano da concisão, não apenas descrevem o espaço onde habita o animal, mas também se referem ao seu modus operandi ("vivo" e "capturo"). Além da visão atenta, a coruja demonstra sua perspicácia por meio da audição, pois é capaz de localizar sua presa a despeito de seu mínimo arfar. Paralelamente, os versos também são indicativos de uma produção poética obcecada pelo que há de mais medular à natureza humana: o "sangue". Interessante notar que essa presa, embora camuflada em meio ao "pleno escuro", é incapaz de escapar à visão privilegiada da coruja. Embora a alusão ao sangue seja feita uma única vez no poema, ele não passa despercebido aos nossos olhos por conta do contraste em relação à escuridão do ambiente. Vale apontar que, no corpo do poema, o verso que menciona o sangue está no limite entre as duas estrofes, indicando o momento de descoberta que antecede 0 ataque. Além disso, o uso dos travessões é significativo, pois exige a suspensão da leitura que antecipa o momento de maior tensão do poema, quando a caça é enfim localizada e dominada. Tal força também pode ser verificada no campo sonoro do poema. $\mathrm{Na}$ primeira estrofe, percebemos que as vogais /o/ e /u/ são acomodadas umas próximas das outras de maneira a provocar uma 
sensação de flutuação, como nos trechos "Voo onde" e "ouço o". Além disso, há a predominância de sons nasais que remete a um estado meditativo. É só a partir da menção ao sangue que, na segunda estrofe, a tensão entre as imagens (coruja, escuro e sangue) é potencializada. Nos três últimos versos, o uso do fonema /p/ presente em sílabas tônicas, está sempre associado a outras consoantes, a saber, /t/, /r/ e /l/, provocando uma sonoridade que remete à investida brusca da ave contra a presa, revelando, conforma aponta Ivan Marques, "a surpresa do ataque e o triunfo da caça, a ponto de quase sentirmos a violência da trituração". ${ }^{46}$

Conforme afirmamos anteriormente, "Coruja" possui uma moldura temático-estrutural que confere circularidade ao poema. Tal movimento ganha maior relevância se pensarmos no deslocamento espacial que a ave realiza rumo ao solo quando finalmente alcança sua presa. Em outros termos, a ave transita entre dois espaços, dada sua condição que exige o voo (Destino) e o ato de caçar (Vontade). Tal oscilação parece se referir ao modo como Orides Fontela arma seus poemas, pois ela faz uso de uma linguagem poética extremamente depurada para representar, de maneira lúcida, o sentimento de inadequação do ser no mundo. Dado o largo uso das imagens sensoriais ${ }^{47}$ para apreender a presa, o poema evita o "enaltecimento de um mistério inacessível" ${ }^{48}$. Ao

\footnotetext{
${ }^{46}$ Ivan Marques, "A um passo do anti-pássaro: a poesia de Orides Fontela". In: Estudos de literatura brasileira contemporânea. Brasília, UnB. Artigo no prelo, não paginado.

47 Quatro são os sentidos mobilizados no poema: visão ("luz" e "escuro"), audição ("ouço"), olfato ("farejo") e tato ("capturo"). Interessante notar que três dos quatro sentidos são descritos por verbos em primeira pessoa, enquanto dois substantivos adjetivados estão ligados à incapacidade de se guiar completamente pela visão ("luz mínima" e "pleno escuro"). No poema "Noturno", da mesma seção de Rosácea, tal dimensão é contemplada em sua segunda estrofe: "os que vão viver apesar / da escuridão e nos olhos / a luz clandestina / acendem". Importante atentar para a postura um tanto hesitante por parte do sujeito lírico perante essa luz que apresenta como clandestina ilegítima. Tal cautela também é posta na primeira estrofe de "Noturno", pois, ao descrever "os que nascem de noite", diz o poema que esses seres "vigiam o fogo", tratando-se tanto de contemplação do fogo como de resguardo e espreita.

${ }^{48}$ Davi Arrigucci Jr., 2005, p.119.
} 
contrário, há uma forma que puxa, de maneira austera, as imagens "para o concreto e a revelação se dá no estar aqui que é problemático, doloroso, sofrido" ${ }^{49}$.

Como tentamos demonstrar, a poesia de Orides Fontela possui uma forte dimensão trágica na medida em que toma a consciência do desajuste como ponto de partida. E é também trágica em virtude da capacidade de representar tais impasses por meio da linguagem artística, aspecto que Schiller julga decisivo para produzir a experiência do sublime, visto que a arte trágica é capaz de "pôr o homem em contato com a lei racional capaz de libertá-lo da causalidade natural, sem torná-lo indefeso, como acontece no caso de uma desgraça real" ${ }^{50}$. Mesmo que se trate de um obstáculo simbólico, a representação da autonomia do sujeito, apesar de exclusivamente no plano artístico, se apresenta como uma "possibilidade de um símbolo de liberdade" ${ }^{51}$.

\footnotetext{
${ }^{49}$ Ibid, p.119.

50 Pedro Süssekind, 2011, p.100.

${ }^{51}$ Ibid, p. 100.
} 


\title{
A DICÇÃO IRÔNICA DE ORIDES FONTELA
}

\author{
É preferível variar de erros a insistir no erro. \\ $O$ avesso das coisas, Carlos Drummond de Andrade ${ }^{52}$
}

Além de representar os impasses de maneira trágica, vemos que a poesia de Orides Fontela oferece outra possibilidade de resposta. Retomando a dicotomia entre Destino e Vontade apresentada no capítulo anterior, parece haver em certos poemas um posicionamento de resistência que se constrói através da ironia que desestabiliza alguns pressupostos sedimentados na e pela linguagem. Tal ideia parte do argumento de que Orides estaria inclinada a instaurar uma mudança em sua obra, tentativa proeminente a partir de Rosácea. Vale reforçar que quando falamos de uma mudança, não pressupomos uma completa virada poética, mas que estamos sinalizado o caráter experimental do livro em virtude de sua estrutura propositalmente heterogênea. De todo modo, talvez seja mais interessante sublinhar que o uso da ironia em seus poemas parece apontar para a possibilidade de que a poeta estivesse atenta à recepção crítica de sua obra.

Em "A nova poesia brasileira e a poesia", artigo publicado em meados da década de 1980, Vinícius Dantas se propõe a realizar o balanço crítico de alguns livros de poesia surgidos em 1983, ano em que Alba, terceiro livro de Orides Fontela, foi lançado ${ }^{53}$. De acordo com o ensaísta, Alba celebra

\footnotetext{
52 Carlos Drummond de Andrade. $O$ avesso das coisas. São Paulo: Editora Record, 1990, não paginado.

${ }^{53}$ Além de Alba, Vinícius Dantas tece comentários gerais sobre Sósia da cópia (Régis Bonvicino), Gigolô de bibelôs (Waly Salomão), Drops de abril (Chacal) e Caprichos e relaxos (Paulo Leminski).
} 
um conceito de poema sublime, amaneirado, elegantemente afastado de qualquer marca desagregadora do real ou da subjetividade; poema que ministra homeopaticamente gotas de plenitude. ${ }^{54}$

Nessa avaliação crítica da poética oridiana, nos chama a atenção a insistência com que Dantas descreve Alba como um "projeto de poema estufado de sublime" ${ }^{55}$. Selecionamos tal comentário direcionado à $A / b a$, livro publicado três anos antes de Rosácea, pois o título com o qual aqui trabalhamos é visto como o fim de um ciclo de obras "nas nuvens" ${ }^{56}$. Rosácea é um livro peculiar, conforme já indicamos, devido à sua estrutura heterogênea, o que poderia ser indicativo de uma ideia de passagem. No entanto, para melhor compreendermos a possível diferença que se apresentaria a partir de Rosácea é fundamental verificar, antes de tudo, a definição de sublime, termo utilizado não só por Vinícius Dantas, mas também pela própria poeta. Para tal fim, nos valeremos do percurso feito por Pedro Süssekind quanto ao uso do termo ao longo dos séculos.

Primeiramente, Süssekind resgata o conceito de sublime dos tratados redigidos por Cássio Longino. Muito embora seus textos discorram acerca da retórica, vemos que Longino salienta como o ápice do discurso a capacidade de "arrebatar, persuadir e agradar como uma força irresistível os ouvintes" ${ }^{57}$. Por si só a eloquência não faz um bom discurso; para que determinado texto seja considerado como dotado de um estilo sublime, falta a ele aquilo que Longino chama de um efeito da poesia. A força do discurso está então menos relacionada ao que o texto possui de persuasão retórica, uma vez que a grandiosidade de certas passagens

\footnotetext{
${ }^{54}$ Vinícius Dantas, 1986, p. 53.

55 Ibid, p. 53.

${ }^{56}$ Trata-se de material ainda inédito concedido por Ivan Marques.

57 Pedro Süssekind, 2011, p. 78.
} 
poéticas é que provocaria uma surpresa arrebatadora no ouvinte. Considerando esse efeito de poesia é que Süssekind traz à discussão a dicotomia entre o prazer positivo e o prazer negativo, elaborada por Edmund Burke. Em linhas gerais, o prazer positivo proviria da delicadeza de objetos pequenos, claros e de dimensões suaves e harmoniosas, se opondo a fenômenos de magnitude superior ao ser humano, como é o caso de tempestades, de animais ferozes ou ainda da escuridão. Essas últimas manifestações seriam as fontes do prazer negativo, que Burke especificamente chama de deleite com o intuito de diferenciá-lo da contemplação própria do prazer positivo. Conforme sublinha Süssekind, tal oposição se deve ao fato de que o prazer positivo está relacionado à beleza, ao passo que o negativo se refere ao sentimento de sublime. Isto é, o prazer negativo se assemelha ao deleite da arte trágica, pois, dada a distância com a realidade, o observador é capaz de sentir prazer através do objeto de desprazer ali representado. Tendo isso em mente, voltaremos nosso olhar para o poema "Kant (relido)", presente na seção "Novos", de Rosácea:

\author{
KANT (RELIDO) \\ Duas coisas admiro: a dura lei \\ cobrindo-me \\ e o estrelado céu \\ dentro de mim.
}

Conforme apontado em seu título, o poema apresenta uma releitura das ideias de Immanuel Kant. Vale comentar que a leitura proposta por Orides inverte, por meio da paródia, o teor da máxima kantiana. Se em Crítica da razão prática o filósofo defende que a lei moral deve guiar o modo de agir do ser humano, como 
um imperativo residindo dentro dele ${ }^{58}$, a poeta desloca tais preceitos para fora do sujeito. Por conta da alteração da perspectiva, o papel que a lei desempenha passa a ser outro, na medida em que deixa de ser imanente para se impor sobre o ser. Ciente de que se trata de uma condição autoritária da qual não se pode esquivar, o sujeito observa "a dura lei" com um misto de espanto e prazer, dimensões abarcadas pelo verbo admirar. Paralelamente, o céu também aparece realocado na leitura oridiana, pois, no texto original, o céu é descrito como estando acima do sujeito, o que de certa forma deflagra a distância entre eles. De acordo com Olgária Matos, tal inversão demonstra que o céu, como símbolo de plenitude, está "não mais na transcendência, mas na imanência do ser" 59 .

É interessante observar que há aspectos sonoros que acompanham a camada semântica do poema. Por exemplo, a aspereza contida no trecho a dura lei vai ao encontro da sonoridade fortemente marcada tanto pela brevidade das vogais como pela presença dos fonemas consonantais sonoros /d/, / $r /$ e /l/. Semelhantemente, o quarto verso - e o estrelado céu - possui uma suavidade, se comparado ao trecho anteriormente citado, graças aos encontros vocálicos próximos ao fonema surdo $/ \mathrm{s} /$, representado pelas consoantes " $s$ " e " $c$ ".

Retornando à diferenciação entre os prazeres positivo e negativo, vemos que o adjetivo que acompanha a lei descreve sua condição áspera. De maneira semelhante, o poema também apresenta a imagem do céu, cuja magnitude não se deixa reduzir

${ }^{58}$ Cf. Immanuel Kant sintetiza tal pensamento na seguinte formulação: "Duas coisas enchem o ânimo de crescente admiração e respeito, veneração sempre renovada quanto com mais frequência e aplicação delas se ocupa a reflexão: por mim sobre o céu estrelado; em mim a lei moral". Rio de Janeiro: Ediouro, p. 143.

${ }^{59}$ Cf. Olgária Matos em depoimento registrado no documentário Orides: a um passo do pássaro. 
por estar localizado dentro do ser. Aliás, o fato de ser um céu estrelado também não ameniza o fato de que se trata de um céu noturno. Ou seja, as duas realidades - o fora e o dentro compõem o estado de espírito do sujeito poético que se deleita tanto com "a dura lei" quanto com "o estrelado céu". Vale mencionar que, embora o poema tenha invertido a construção do pensamento kantiano, ambas as dimensões tocam na questão do sublime, pois, ao retomar a noção de deleite proposta por Burke, se constrói em "Kant (relido)" o efeito de poesia através de "um prazer que vem do desprazer" 60 .

No quadro da discussão teórica que Pedro Süssekind elabora, vemos que tanto Burke como Kant apontam para a possibilidade de gerar o sublime em face ao objeto que nos causa temor. Conforme observa Süssekind, é graças a Schiller que a discussão avança, em virtude da defesa da existência de outra categoria de sublime que inclui a representação do sofrimento (pathos). O sublime patético considera não só a hostilidade do objeto, mas o sofrimento do sujeito, transpostos nos "limites de uma experiência prazerosa" ${ }^{61}$. Vale observar que, em alguns poemas de Orides Fontela, a distância entre sujeito e objeto é difícil de ser mensurada. Como vimos no capítulo anterior, há em "O espelho" a delicada relação entre a imagem apresentada no título e o sujeito, por conta da oscilação entre o afastamento e a aproximação em direção ao objeto. De todo modo, podemos pensar que há a representação do sublime patético no referido poema, a despeito da cautela que o sujeito demonstra. Já em "Kant (relido)", a presença do pathos é mais evidente por conta da marcada distinção entre o sujeito (figurado pelo estrelado céu) e o objeto (representado pela dura lei). Vale insistir no fato de que o poema constitui uma paródia,

\footnotetext{
${ }^{60}$ Pedro Süssekind, 2011, p. 84.

${ }^{61}$ Ibid, p. 94.
} 
gênero textual que realiza a inversão de seu texto fonte. Conforme aponta Linda Hutcheon, está na base da paródia "uma distanciação crítica entre o texto em fundo a ser parodiado e a nova obra que incorpora, distância geralmente assinalada pela ironia" ${ }^{62}$. Ou seja, ao realizar a quebra da expectativa em "Kant (relido)", o poema constrói uma representação da resistência mediante a relativização dos pressupostos da máxima kantiana.

Antes de prosseguirmos na análise de outras manifestações da ironia na poética oridiana, vale comentar sobre como o uso da linguagem prosaica é carregada de visões de mundo de que acabamos por usar sem muito refletir. Por exemplo, o emprego de clichês facilita a comunicação por se tratar de expressões socialmente partilhadas que automatizam a compreensão do conteúdo que queremos transmitir ${ }^{63}$. Tomemos como exemplo de clichê a frase que inicia diversas adivinhas da cultura popular: "o que é, o que é?". No uso corriqueiro da linguagem, esse fragmento de discurso antecipa a descrição de enigmas variados. Ou seja, tal expressão cumpre a função fática, pois privilegia a interação entre emissor e receptor, preparando o interlocutor para receber a informação que virá a seguir. Orides Fontela transforma esse clichê em poema, como vemos nos versos a seguir, inclusos na seção "Lúdicos", de Rosácea:

\footnotetext{
${ }^{62}$ Linda Hutcheon, Uma teoria da paródia. Ensinamentos das formas de Arte do século XX. Lisboa: Edições 70, 1985, p. 48.

63 João Adolfo Hansen nos ajuda a melhor compreender a ideia de repetição mecânica contida na acepção do termo "clichê", ao resgatar sua origem, remetendo a Francis Goyet: "(...) clichê é o nome da placa de metal que é usada como molde para imprimir a página inteira de um texto; com a placa é possível fazer tiragens ilimitadas dele, sem necessidade de usar caracteres móveis.". João Adolfo Hansen. Lugar-comum. In: Adma Muhana e Luiz Armando Bagolin (orgs.). Retórica. São Paulo: Annablume, 2012, p. 159.
} 
DA METAFÍSICA

(OU DA METALINGUAGEM)

O que é

o que

é?

Como se vê, "Da metafísica (ou da metalinguagem)" recorre à expressão tautológica para usá-la como paródia. Ao que nos parece, a composição substitui a sentença por um questionamento reflexivo. Vemos que a adivinha sofreu apenas duas alterações ao ser transformada em poema: além da perda da vírgula, a expressão foi divida em três versos. Ou seja, muito embora as modificações realizadas na paródia oridiana sejam sutis, vemos que elas alteram o modo de ler e, consequentemente, o sentido. Se na formulação original a pausa era marcada pela vírgula após o primeiro verbo "é", no poema a suspensão da leitura acaba ocorrendo ao fim do segundo verso. Desse modo, o trabalho da linguagem poética desloca o conteúdo sedimentado na linguagem prosaica, gesto que deflagra a indagação do estado das coisas. É nesse sentido que o subtítulo do poema aponta não para o uso da palavra como mero instrumento de comunicação; a linguagem é veículo de questionamento de si própria, mas também da realidade à qual está relacionada.

Outro tipo de expressão consolidada na sabedoria popular é o provérbio, que nada mais é do que um clichê, uma repetição sem variações de determinada sentença. Além da repetitividade como característica identificadora do provérbio, Dominique Maingueneau comenta seu aspecto polifônico, pois o discurso do enunciador retoma "inumeráveis enunciações anteriores, as de todos os locutores que já proferiram aquele provérbio" ${ }^{64}$. Tomemos como

64 Dominique Maingueneau. Do provérbio à ironia: polifonia, captação e subversão. In Análise de textos de comunicação. São Paulo: Cortez, 2008, p.15. 
exemplo a expressão latina Veni, vidi, vici, traduzida como "Vim, vi, venci", atribuída ao imperador romano Júlio César. Essa frase é comumente utilizada para expressar não só o empenho, mas também o êxito de seu locutor em determinado empreendimento. Tal provérbio foi utilizado por Orides Fontela como base para a formulação do poema "O anti-César", também pertencente ao bloco intitulado "Lúdicos":

O ANTI-CÉSAR

Não vim.

Não vi.

Não havia guerra nenhuma.

Ao cotejarmos a paródia que se apresenta nesse poema com a que foi realizada em "Da metafísica (ou da metalinguagem)", percebemos que há maior intervenção formal. Embora o poema rearranje as ações ao longo de seus três versos, o nexo que existe na frase original persiste na paródia através da relação de causa e efeito às avessas, já que os três versos se iniciam com a negação dos verbos. A realização da paródia de um provérbio, seja ele qual for, é geradora de significado. Conforme observa Maingueneau, a subversão proposta na feitura de um provérbio paródico é a contestação do provérbio (como forma) e da sabedoria popular (como conteúdo). Bucioli vê nesse poema de Orides a possibilidade de o sujeito escrever uma nova historia que não a de César, como se fosse uma narrativa em contraposição ao caráter heroico da máxima original ${ }^{65}$. De fato, o poema contraria a diç̧ão grandiloquente do provérbio. Nesse ponto, Villaça vai além ao afirmar que por detrás do aparente tom leve do poema não há "qualquer concessão ao barateamento do anedótico, da paródia

${ }^{65}$ Cf. Cleri Aparecida Biotto Bucioli, 2003, p. 119. 
frívola" ${ }^{66}$, pois como temos visto, o uso da ironia redimensiona criticamente a perspectiva. O crítico conclui que há em "O antiCésar" a dicção de um sujeito resignado, numa espécie de "aceitação de fatalidade sem batalha" ${ }^{67}$. Com efeito, essa leitura é possível considerando que o sujeito se abstém das ações que não realiza. Por outro lado, as negativas do poema também parecem apontar para uma disposição um tanto humilde do sujeito que reconhece não haver triunfado sobre o conflito imposto pelo Destino. Pensar na ideia de humildade parece ser mais produtivo, pois, além de se referir à submissão, conforme apontado por Villaça, tal termo carrega simultaneamente a feição comedida tão própria da poética oridiana. De todo modo, esse caráter austero não impede o poema de conter o tom jocoso que avalia a tensão trágica ali posta, sem necessariamente acrescentar um aspecto depreciativo em relação ao texto original, pois, como afirma Hutcheon, a ironia da paródia "tanto pode ser criticamente construtiva, como pode ser destrutiva" ${ }^{68}$. Aliás, é nesse jogo de indeterminação que a ironia opera, pois é próprio à sua natureza "ser muitas vezes insolúvel, impedindo que o co-enunciador determine se o enunciador está ou não sendo irônico" ${ }^{69}$.

Vale comentar que Orides Fontela, na seção "Lúdicos" de Rosácea, também lança mão da paródia tendo como base poemas de Carlos Drummond de Andrade para compor "CDA (imitado)" e "CDA (relido)".

\footnotetext{
${ }^{66}$ Alcides Villaça, 2015, p. 307.

${ }^{67}$ Ibid, p. 307.

${ }^{68}$ Linda Hutcheon, 1985, loc. cit.

${ }^{69}$ Dominique Maingueneau, 2008, p. 176.
} 
CDA (IMITADO)

Ó vida, triste vida!

Se eu me chamasse Aparecida

dava na mesma.

Ao se apropriar da sexta estrofe do "Poema de sete faces", do livro Alguma poesia, Orides toma o poema de Drummond como objeto não de confronto, mas de ponto de partida para tratar dos próprios obstáculos. Apesar de reconhecermos a comicidade do poema, seu caráter trágico ainda é mais forte, dada a presença do sofrimento no "discurso feminino de um gauche de saias, que ainda por cima teve a infelicidade de nascer na pobreza" ${ }^{70}$, conforme observa Ivan Marques.

Se em "CDA (imitado)" o tom pessimista, de certa forma, prevalece, em "CDA (relido)" o ajuste irônico tem peso mais forte:

CDA (RELIDO)

Caio ver

ticalmente

e me transformo.

Orides resgata o último verso de "Morte no avião", do livro $A$ rosa do povo, de modo a operar duas modificações formais: realiza o corte do verso original transformando-o em três, além de alterar a regência do verbo transformar ${ }^{71}$. Ambas as estratégias apontam para uma relação de causa e efeito entre os dois verbos do poema: "caio" e "me transformo". Na menção desta queda ecoam tanto a ideia de "cair em si", como sinônimo de tomada de consciência, quanto uma força gravitacional em direção ao plano terrestre. De todo modo, as duas leituras se relacionariam como causa da

\footnotetext{
${ }^{70}$ Trata-se de material ainda inédito concedido por Ivan Marques.

${ }^{71}$ Ibid.
} 
transformação pela qual passa o sujeito do poema. Em outras palavras, vemos que as duas composições feitas a partir de Drummond dialogam com as dimensões do Destino e da Vontade, pois há em "CDA (imitado)" o caráter mais trágico e em "CDA (relido)" uma abertura para a possibilidade de autonomia do sujeito.

Tendo acompanhado o percurso que Pedro Süssekind elabora em torno das diversas leituras do conceito de sublime desenvolvidas ao longo de séculos, um aspecto nos chama atenção. Independente dos caminhos que a filosofia moderna propôs - a saber, Burke, Kant e Schiller -, nenhum desses teóricos parece ter se afastado das cinco fontes capazes de produzir o estilo sublime, divisão elaborada pelo retórico romano Cássio Longino (2005 apud SÜSSEKIND, 2011, p. 79), como se vê na seguinte proposição:

(1a) capacidade de se elevar a pensamentos grandiosos; ( $\left.2^{a}\right)$ emoção veemente e inspirada; ( $3^{a}$ ) determinada moldagem das figuras, do pensamento e da palavra; (4a) nobreza de expressão; (5a) composição com vistas à dignidade e elevação ${ }^{72}$.

Considerada a devida diferença entre o modo como o fazer poético era visto na Antiguidade Clássica e no mundo contemporâneo, no que diz respeito à inspiração, vale observar que alguns aspectos apontados por Longino são pilares da poesia de Orides Fontela, a exemplo da operação intelectual em torno de temas grandiosos. Além disso, vemos como a representação desses mesmos temas, seja com conceitos ou com imagens, por meio do trabalho com a linguagem, que medita sobre os impasses, tema que nos parece central em Rosácea. Ou seja, a crítica que Vinícius Dantas dirige à poética oridiana é apenas correta pelo fato de 0

${ }^{72}$ Cássio Longino. Do sublime. In: A poética clássica. São Paulo: Cultrix, 2005, p. 77. 
autor usar o termo "sublime" para qualificá-la. A legitimidade de seu argumento parece não ir adiante, pois o que Dantas considera como sublime não condiz com as definições anteriormente apresentadas, já que o crítico julga não haver marca sequer de objetividade e lucidez nos poemas de Orides Fontela.

Interessante notar que, embora os poemas de Orides tematizem o impasse da construção de sua identidade poética, isso ocorre dentro de um quadro de alta reflexão crítica, sem incorrer num tom confessional. Tal ambivalência entre apagamento $e$ revelação da subjetividade deflagra a tensão de sua obra, aspecto muito caro à poesia moderna. Um bom exemplo desse tipo de tensão se dá na inversão de imagens e conceitos fixados no senso comum, como se vê em "Pirâmide", poema que integra o bloco "Novos":

\title{
PIRÂMIDE
}

\author{
Ei-la \\ dor de milhares força \\ de humanidade \\ anônima
}

(do faraó

nem cinzas).

De maneira aparente, o poema remete aos monumentos funerários construídos no Antigo Egito tidos como símbolo e mecanismo de ressureição, em virtude da menção ao faraó. O poema inicia com o uso do termo denotativo, que cumpre a função de apontar a imagem, em relação à qual o sujeito poético se encontra numa relação de proximidade espacial. Tal apontamento também serve como mote para a descrição da pirâmide nos versos seguintes, sustentada na oposição entre dois sujeitos: a 
"humanidade" (igualmente referida no plural "milhares") e o "faraó". A descrição dessa desigualdade é importante para o deslocamento do senso comum que o poema cria. Se o discurso habitual tem por costume ressaltar a grandiosidade das pirâmides como reflexo da riqueza cultural das populações antigas, o poema se abstém de tecer comentários dessa natureza. Ao contrário, ele é enfático ao descrever a magnitude do sofrimento dos pobres e dos escravos que ergueram tal monumento. Isso posto, observamos a relação entre poder e identidade, dada a dicotomia assimétrica entre a massa anônima de escravos e os faraós, cujos nomes foram preservados ao longo dos séculos.

Vemos que a segunda estrofe, um dístico composto por quatro palavras, duas em cada verso, desestabiliza todo o conteúdo anteriormente apresentado. Enquanto na primeira estrofe se apresenta a pirâmide de maneira um tanto genérica, o comentário entre parênteses ao final do poema aponta um aspecto pouco usual desta imagem, observação que a particulariza. Nesse processo, a ironia se converte na reflexão crítica do discurso histórico, pois apresenta a relação opressora entre base e topo piramidal. A partir disso, notamos que a imagem tematizada no poema também pode ser representativa da estrutura de classes sociais. É nesse sentido que a construção do poema parece oferecer uma alternativa a esta estrutura, como se vê na disposição de seus dois polos. De maneira invertida, o poema traz a massa amorfa - a "humanidade/anônima" - em primeiro plano, enquanto que a representação soberana do faraó está situada nos últimos versos. Tal geografia não parece despropositada, ainda mais se atentarmos à expressão que chama a atenção para o sofrimento dos oprimidos - "ei-la" - ao passo que a figura faraônica se apresenta como que oculto entre parênteses. Em outras palavras, o desmonte do senso comum proposto no poema 
parece se confirmar como parte da toada irônica adotada por Orides. É interessante notar a articulação entre a camada evidentemente mais irônica e o fundo trágico na poética oridiana, uma vez que a representação do sofrimento por meio do sublime patético não se dissocia da luta contra o uso gasto da linguagem ${ }^{73}$.

O percurso que realizamos até então se pautou pela observação das variadas maneiras com que a poética de Orides Fontela se esforça em desmontar pressupostos que a linguagem cotidiana carrega. Vimos que o uso da ironia no tratamento dos clichês desloca nossa atenção para o caráter processual da reflexão. Melhor dizendo, em vez de aceitar dado objeto como verdade, os poemas privilegiam a construção do pensamento. Vemos então que a poética oridiana reconhece os limites da realidade sem, no entanto exaltá-la, gesto que muito representa a definição do existencialismo proposta por Nicola Abbagnano, que a descreve como a filosofia capaz de destacar polemicamente as instabilidades, os contrastes, os aspectos negativos e desconcertantes que a existência oferece ${ }^{74}$. Nos poemas de Orides, tais incertezas se mostram tanto como um dos temas centrais de sua obra quanto no seu modo de fazer poesia. Ao afirmar que em sua poética está contida a máxima atenção, a cautela, a consciência, a lucidez, a reflexão analítica, dentre outros termos, estamos no fundo nos referindo ao tatear dos aspectos mais obscuros e incertos da existência como o caminho pelo qual o

\footnotetext{
${ }^{73}$ Aliás, são estes dois pontos que Schiller considera como condições primordiais do sublime patético na arte trágica: "Em primeiro lugar, uma representação vivaz do sofrimento, de modo a despertar o afeto compassivo com intensidade apropriada. Em segundo lugar, uma representação da resistência contra o sofrimento, de modo a chamar à consciência a liberdade interna do ânimo. Somente por meio da primeira o objeto se torna patético, apenas por meio da segunda se torna o patético também sublime". Friedrich Schiller, Sobre o Sublime. In: Pedro Süssekind (org.) Friedrich Schiller. Do sublime ao trágico. Belo Horizonte: Autêntica, 2011, p. 51.

74 "(...) l'esistenzialismo si iscrivi in falso e tendo a mettere polemicamente in luce l'instabilità, il contraste, gli aspetti negativi e sconcerdante, che l'existenza offre (...)". Nicola Abbgnano. Possibilità e libertà, 1956. p. 15., tradução nossa.
} 
sujeito opta seguir. Exemplo bem claro desse assunto está posto em "Viagem", poema da seção "Novos", na medida em que a indeterminação do destino se torna a discussão central.

\author{
VIAGEM \\ Viajar \\ mas não \\ para \\ viajar \\ mas sem \\ onde
}

sem rota sem ciclo sem círculo

sem finalidade possível.

Viajar

e nem sequer sonhar-se

esta viagem.

É necessário dizer que nem sempre o diálogo com o senso comum se faz por meio da paródia, pois, como vemos em "Viagem", não há qualquer texto usado como base para a composição. Mesmo não havendo o uso da paródia, percebemos que ao longo das quatro estrofes o poema alude ao deslocamento como mote para a particularização de seu sentido no interior do poema.

Em primeiro lugar, chama a atenção o escasso uso de ações, pois além das três ocorrências de "viajar", há o verbo "sonhar" no décimo verso, cuja agência recai sobre a própria ação tematizada ao longo do poema. Dado uso do modo infinitivo dos verbos, tais ações não estão postas em prática. No entanto, não escapa à nossa leitura que as repetições do verbo "viajar" se relacionam ao caráter 
inevitável do Destino. Importante apontar que a insistente menção deste percurso incontornável, que é a própria existência, diz muito a respeito do caráter reflexivo da poética oridiana. Em segundo lugar, outro aspecto que salta aos nossos olhos é a reiterada negação que chega a ser estrutural no poema. Como podemos observar, as palavras "não", "sem" e "nem" são mobilizadas não para negar a viagem em si, mas para qualificá-la. A perspectiva pela qual a ideia de viagem é moldada no poema se dá por conta dos comentários que são introduzidos após tais negativas, na medida em que elas especificam o que (não) se pode esperar desta viagem. Nas duas primeiras estrofes se introduz a noção de que o caminho é mais importante de que o destino final, aspecto que é detalhado na terceira estrofe. Embora não haja a repetição do verbo "viajar" como há nas demais estrofes, vemos que os versos 7 e 8 possuem um paralelismo particular, devido às quatro ocorrências do termo "sem". A insistência dessa palavra pode dar margem a duas leituras que não são de todo conflitantes. Por um lado, podemos pensar que o sujeito reconhece que tal viagem é irregular por natureza, por assim dizer, uma vez que não há um roteiro a ser seguido. Por outro lado, é também possível entender que o sujeito é quem recusa passar por caminhos já antes percorridos, não só pela negação do termo "rota", mas também pela veemência com que rejeita estruturas vedadas, ensimesmadas - "sem ciclo" e "sem círculo" - , dada a ausência de abertura para criar o próprio caminho. De todo modo, as duas interpretações não estão distantes da postura do sujeito que enfatiza o momento do traslado em detrimento do local de chegada. Tal gesto anuncia a ausência de uma direção programada - "sem rota" - numa espécie de abertura ao novo e ao desconhecido.

Retomando a discussão sobre a distinção ente paródia e alusão, vale comentar que ambas possuem pontos de contato, em 
virtude do fato de que ambas são estruturas que essencialmente se constituem por meio de empréstimos textuais. No entanto, a distinção entre elas se dá pelo fato de que a paródia necessariamente critica o texto em qual se baseia. Já a alusão pode ter um fundo crítico na medida em que amplia a ideia apresentada pelo seu texto suporte. Em outras palavras, a paródia contém a alusão, mas a segunda prescinde da primeira. Tendo isso em mente, as duas proposições da sabedoria popular - a saber, "quem procura, acha" e "errar é humano" - dialogam com o poema "Errância", presente no bloco "Novos".

ERRÂNCIA

Só porque

erro

encontro

o que não se

procura

só porque

erro

invento

o labirinto

a busca

a coisa

a causa da

procura

só porque

erro

acerto: me

construo 
Margem de

erro: margem

de liberdade.

Vemos que em boa parte das estrofes a noção de erro é descrita como força desencadeadora das demais ações do poema. Numa relação de causa e efeito, o sujeito somente é capaz de encontrar (estrofe 1), inventar (estrofe 2) e acertar (estrofe 4) após ter se submetido ao erro. Vale reforçar que o termo "só" restringe tais consequências à ação primeira relativa ao erro. Ou seja, a primeira estrofe pode ser lida como uma paródia do ditado popular "quem procura, acha" na medida em que os fundamentos de ambas as descobertas discordam entre si, pois no ditado a ênfase está na busca enquanto que no poema nega-se o interesse em uma finalidade específica, resultando no encontro ao acaso graças ao erro.

Considerando-se o caráter formativo que o erro desempenha na primeira estrofe, vale a pena verificar como essa ideia aparece no restante do poema. Na segunda estrofe, por exemplo, percebemos que a imagem do labirinto também ganha uma representação peculiar visto que seus meandros não são dados ao sujeito de maneira apriorística. É de fato o sujeito, por meio do erro, que constrói seu próprio caminho. Tal mudança de perspectiva oferece uma autonomia que a tradicional estrutura do labirinto não apresenta, devido a sua rigidez.

Já a terceira estrofe não repete o padrão das anteriores por não apresentar o paralelismo "só porque / erro". Além disso, se trata de construção nominal, enquanto que as estrofes anteriores possuem verbos. No entanto, a ausência de verbos não impede o poema de estabelecer uma aproximação semântica dos termos dado o encadeamento dos versos. Se torn então legítima a relação de equivalência entre os versos, como se o sujeito não priorizasse "a coisa" sobre "a busca". 
Ao retomar a estrutura paralelística na quarta estrofe, o poema reafirma o erro como algo construtivo. É nesse sentido que a alusão ao aforismo "errar é humano" aponta para a nossa capacidade de aprender a partir das próprias falhas. A conotação negativa que o termo erro adquiriu em nossa cultura se mostra então passível de mudança conforme a perspectiva adotada. Como observa Abbagnano, o erro "não pertence à esfera das proposições (ou dos enunciados), mas à do juízo das atitudes valorativas" ${ }^{75}$. A consciência da disjunção do valor negativo para com o erro permite encarar o novo caminho como possibilidade de liberdade, como se vê na síntese da última estrofe, dada a necessidade de sair do centro e apostar no erro como possibilidade de autonomia, ocupando um espaço à margem.

Merece também destaque o uso dos verbos na primeira pessoa do singular - "erro", "encontro", "invento", "acerto" e "construo" - visto que esse gesto demonstra o interesse em buscar uma identidade própria, opondo-se à leitura corrente da obra de Orides como uma poesia despersonalizada. Os verbos destacados também indicam uma sucessão gradativa das ações, o caos e a ordem constituindo os extremos complementares de um mesmo processo. Fica evidente a tentativa de Orides de caracterizar essa multiplicidade como uma qualidade inerente ao "mais belo universo" aludido no prefácio de Rosácea. Além disso, vale comentar que esse esforço é antes um desejo de autonomia através da liberdade que se apropria da linguagem de modo a transformá-la, como se vê na conversão do questionável "erro" em "acerto". Essa aguda consciência que perpassa o poema amplia, por assim dizer, o campo semântico referente à "errância". Vemos que das quatro ocorrências do vocábulo "erro" no poema, as três primeiras são flexões do verbo "errar", tendo por sinônimo a ação

75 Nicola Abbagnano, 2007, p. 341. 
de "vaguear". Por meio do trocadilho, observamos o desejo de transformar o erro em autonomia graças ao caráter espiralar de Rosácea que reatualiza as imagens e a linguagem a partir de um novo ponto de vista. Além disso, a ideia de vaguear contida em "erro" confere um caráter pedestre ao poema, leitura que de maneira alguma nega a possibilidade anterior, pois conforme observa Arrigucci Jr., a busca pela essência das coisas na poética oridiana "é um peso e não um trampolim para a transcendência, o que torna o problema concreto e dá muita força para a sua lírica" 76 .

Não coincidentemente a troca do sinal negativo pelo positivo em "Errância" estava dada na epígrafe de Rosácea, uma vez a desordem é descrita como "o mais belo universo". A escolha em ir contra o senso comum, embora suscite o embate de ideias, é aqui apresentada como um gesto quase que catártico de auto-aceitação. Ao admitir o erro como traço constitutivo de sua identidade, anulase o peso da culpa, procedimento semelhante ao proposto no poema "Ananke", que compõe a seção "Mitológicos":

ANANKE

Não há culpa

não há desculpa

não há perdão.

Conforme apontado por Gonçalves, "compreender-se errante é admitir-se subjugado por Ananke" 77 , pela fatalidade do Destino. A partir desta perspectiva, é importante sublinhar que negação do perdão nos versos 2 e 3 não se trata da recusa em concedê-lo. Partindo da premissa de que tais imperfeições existem não como defeito, mas como marca própria - não há culpa -, esvai-se a necessidade do perdão ou da justificativa mediante o "erro".

\footnotetext{
${ }^{76}$ Davi Arrigucci Jr., 2005, loc. cit.

77 Roberta Andressa Villa Gonçalves, 2014, p. 106.
} 


\section{CONSIDERAÇÕES FINAIS}

Ao longo desta dissertação, procuramos demonstrar que o livro Rosácea aponta para a necessidade de mudança na produção de Orides Fontela. Durante nosso levantamento teórico, privilegiamos os estudos que tentaram estabelecer definições de sua obra. O cotejo entre tais textos críticos e a leitura de Rosácea nos permitiu verificar que o caráter heterogêneo do livro muito se refere à tentativa de inflexão poética. Acreditamos ter sido possível apresentar esse fôlego distinto não só através da análise individual dos poemas, mas também por meio da observação do diálogo que eles estabelecem entre si.

Assim sendo, o capítulo 1 forneceu uma visão geral da estrutura de Rosácea pautada na relação a priori conflitante entre suas seções. $O$ trajeto que seguimos demonstrou que, a despeito dos eixos temáticos e temporais de cada bloco, o livro apresenta a consciência dos impasses como argumento unificador. Mais do que simplesmente reconhecer a ambivalência entre o múltiplo e a unidade desse caosmos, o horizonte de nossa pesquisa foi pautado por duas questões: 1 ) de quais maneiras o impasse é tematizado em Rosácea? e 2) o que tais representações nos dizem sobre o modo como Orides Fontela avalia sua obra?

Como vimos, tentamos responder a primeira pergunta no decorrer dos dois capítulos seguintes. Partindo do princípio de que a construção de sua diç̧ão poética se faz ao tematizar o reconhecimento dos próprios obstáculos, tal incorporação do desajuste revela a experiência negativa do sublime. De maneira trágica, o sujeito constata a força do Destino que se impõe sobre ele. Apesar das limitações apresentadas, não podemos afirmar que o sujeito se resigna de maneira absoluta. O que de fato notamos é 
uma dicção poética um tanto inconformada diante da constatação de seus impasses.

O uso da ironia prenuncia uma modulação nova na poética oridiana. Ela é empregada como forma de desestabilizar certos paradigmas cristalizados pela linguagem corrente. Vimos que isso se dá tanto através da alusão a lugares comum, como elemento modulante do discurso prosaico, quanto por meio da paródia de clichês (expressões da sabedoria popular, a exemplo do provérbio) e de textos poéticos de outros autores. $O$ tom irônico nos poemas que analisamos faz com que lancemos um olhar diferente para as imagens e construções mobilizadas. Em outras palavras, a percepção se desautomatiza ao lidar não com o objeto (imagem, palavra) barateado no mundo, mas ao privilegiar 0 redimensionamento do nosso juízo.

O principal objetivo desta dissertação foi demonstrar que em Rosácea a errância é apresentada em sinal positivo, sinônimo de escolha em resistência à fatalidade. O que propomos não tem a intenção de desqualificar os estudos que compõem a fortuna crítica oridiana, mesmo porque a medida da inflexão em sua obra está mais no âmbito da tentativa do que da realização concreta. Não se trata também de hipervalorizar sua poética, o que não nos impede, no entanto, de apontar as peculiaridades de Rosácea. Logo, esperamos que as reflexões aqui apresentadas possam se mostrar relevantes no debate da poesia oridiana considerando o caráter experimental deste livro, uma vez que a perturbação trágica e o choque irônico são postos lado a lado como possibilidades de (re)construção de sua voz poética. 


\section{REFERÊNCIAS BIBLIOGRÁFICAS}

\section{Da autora}

FONTELA, Orides. Alba. São Paulo, Roswitha Kempf Editores, 1983. . Trevo. São Paulo: Duas Cidades, 1988.

- Trevo: entrevista de Orides Fontela. In: OHATA, Milton. Inventando, no 1, Faculdade de Direito, USP, 1989.

. Nas trilhas do trevo. In: MASSI, Augusto (Org.). Artes

e ofícios da poesia. 1. ed. Porto Alegre/ São Paulo: Artes e Ofícios/ Secretaria Municipal de Cultura de São Paulo, 1991. v. 1.

. Teia. São Paulo: Geração Editorial, 1996.

- Entrevista concedida ao programa Jô Onze e Meia. Disponível em: https://youtu.be/AN6-FP71xl8 Acessado em: 17 de junho de 2018 às 18 h08.

. Entretien avec Orides Fontela. In: RIAUDEL, Michel. Le Conte et la ville: etudes de literature portugaise et brésilienne. Paris: Presses de La Sorbonne Nouvelle, 1998.

- Sobre poesia e filosofia - um depoimento. In: PUCHEU, Alberto (org.). Poesia (e) filosofia. Rio de Janeiro: 7 Letras, 1998.

. Poesia Reunida [1969-1996]. Cosac Naify: Rio de Janeiro: 7 Letras, 2006.

\section{Sobre a autora}

ALMEIDA, Laura Beatriz Fonseca de. "Prefácio" de Entretecer e tramar uma teia poética: a poesia de Orides Fontela. São Paulo: 
Annablume, Fapesp, 2003.

ANDRADE, Alexandre de Melo. Orides Fontela: A poética do retorno. In: Darandina - Programa de Pós-Graduação em Letras / UFJF - volume 2 - número 2.

ANTUNES NETO, Raul. A condição humana na poesia de Orides Fontela. In: Ângulo 117/8, 2010.

ARRIGUCCI JR., Davi. Na trama dos fios, tessituras poéticas. Depoimento a Cleri Aparecida. Biotto e Laura Fonseca de Almeida. In: Jandira, n02, Juiz de Fora, outono de 2005.

BUCIOLI, Cleri Aparecida Biotto. Entretecer a tramar uma teia poética: a poesia de Orides Fontela. São Paulo: Annablume: Fapesp, 2003.

CANDIDO, Antonio. "Prefácio" de Alba. SP: Roswitha Kempf, 1983. . "Orelha" de Trevo (1996-1988). SP: Duas Cidades, 1988.

CASTELLO, José. "Orides Fontela resiste à sofisticação da poesia". In: O Estado de S. Paulo, 1 de junho de 1996.

COSTA, Alexandre Rodrigues. A construção do silêncio: um estudo da obra poética de Orides Fontela. In: Periódico Eletrônico do Programa de Pós-Graduação em Estudos Literários da UFMG, v. 6, p. 67, Belo Horizonte, 2003.

DANTAS, Vinícius. A nova poesia brasileira e a poesia. Novos Estudos CEBRAP, no 16, SP, dezembro de 1986.

EMEDIATO, Luiz Fernando. "Orelha" de Teia. São Paulo: Geração Editorial, 1996.

FELIZARDO, Alexandre Bonafim. Orides Fontela: a palavra entre o ser e o nada. In: Voos Revista Polidisciplinar Eletrônica da 
Faculdade Guairacá 1.1, 2010.

FERREIRA, Letícia Raimundi. A lírica dos símbolos de Orides Fontela. Rio Grande do Sul, ASL: Pallotti, 2002.

GOMEZ, Yoanky Cordero. Gómez, Yoanky Cordero. A construção do silêncio no discurso poético de Dulce María Loynaz e Orides Fontela: um estudo comparativo. Tese de doutorado apresentada ao Programa de Pós-Graduação em Letras da UNESP, 2016.

GONÇALVES, Roberta Andressa Villa. Entre a Potência e a Impossibilidade: um estudo da poética de Orides Fontela. Dissertação de mestrado apresentada ao Programa de PósGraduação em Literatura Brasileira do Departamento de Letras Clássicas e Vernáculas, FFLCH, USP, 2014.

LIMA, Maria José Batista de. Entre "Trama" e "Teia": a metapoesia em Orides Fontela. Revista Fronteiraz Volume 5-no 5-Agosto/2010.

LÍSIAS, Ricardo. Intervenções: álbum de crítica. São Paulo: Geléia Real, 2014.

MARQUES, Ivan. Documentário Orides: a um passo do pássaro. São Paulo, TV Cultura, maio de 2000. Disponível em: https://youtu.be/19XbX8JTMXI Acessado em: 18 de fevereiro de 2017 às $11 \mathrm{~h} 58$.

- A um passo do anti-pássaro: a poesia de Orides Fontela. In: Estudos de literatura brasileira contemporânea. Brasília, UnB. Artigo no prelo.

MASSI, Augusto. Alba. In: Colóquio / Letras, n.o 76, Lisboa, Novembro de 1983.

. Uma obra feita em espiral. In: Folha de S. Paulo. 9 de Agosto de 1986.

., QUINTILIANO, Flávio e CANÇADO, José Maria. Entrevista 
Poesia, sexo, destino: Orides Fontela. In: Leia Livros. São Paulo, 23 de janeiro de 1989.

ORIONE, Eduino José de Macedo. Filosofia e poesia em Orides Fontela. In: Fronteiraz, Revista Digital do Programa de Estudos dos Pós-Graduandos em Literatura e Crítica Literária da PUC-SP, no 5, agosto de 2010 .

OSAKABE, Haquira. "O corpo da poesia. Notas para uma fenomenologia da poesia, segundo Orides Fontela." Remate de Males 22.2, 2012.

PASCHOA, Priscila Pereira. O ritmo na poesia de Orides Fontela como elemento desarranjador de uma aparente imobilidade no texto literário. In: Letras \& Letras 21.2, 2007.

RIAUDEL, Michel. Trevo. In: Infos Brésil: Le Brésil en France. Paris: out. 1989.

SOTTILLI, Tiago Andrea. 'A palavra é densa e nos fere': trabalho e arte na poesia de Orides Fontela. Dissertação de mestrado apresentada ao Programa de Pós-Graduação em Literatura do Departamento de Teoria Literária e Literaturas da UnB, 2014.

SÜSSEKIND, Flora, Tânia Dias, and Carlito Azevedo, eds. Vozes femininas: gêneros, mediaçòes e práticas da escrita. 7Letras, 2003. VILLAÇA, Alcides. O espelho de Orides. In: Folha de S. Paulo. 9 de novembro de 1988.

- Símbolo e acontecimento na poesia de Orides. In: Estudos Avançados, no 29.85 (2015).

WISNIK, José Miguel. Transparência de esfinge. IstoÉ, São Paulo: 20 dez. 1986. 


\section{Geral}

ABBAGNANO, Nicola. Dicionário de filosofia. São Paulo: Martins Fontes, 2007.

. Possibilità e libertà. Torino: Taylor Torino, 1956.

ADORNO, Theodor W., "Palestra sobre lírica e sociedade". In: Notas sobre literatura I. São Paulo: 2012.

ANDRADE, Carlos Drummond de. Obra completa. Rio de Janeiro: Companhia Nova Aguilar Editora, 1964. . O avesso das coisas. São Paulo: Editora Record, 1990.

ARRIGUCCI Jr., Davi. Humildade, paixão e morte: a poesia de Manuel Bandeira. São Paulo: Companhia das Letras, 1990.

BANDEIRA, Manuel. Antologia poética. Rio de Janeiro: Nova Fronteira, 2001.

BERARDINELLI, Alfonso. Da poesia a prosa. Org. Maria Betânia Amoroso. São Paulo: Cosac Naify, 2007

BISCHOF, Betina. Razão da recusa: um estudo da poesia de Carlos Drummond de Andrade. São Paulo: Nankin, 2005.

BOSI, Alfredo. O Ser e o Tempo da Poesia. São Paulo: Cultrix. 1977.

- Historia concisa da literatura brasileira. São Paulo: Cultrix, 1994.

. Céu, inferno. São Paulo: Editora 34, 2003.

CAMILO, Vagner. Drummond da Rosa do Povo à Rosa das Trevas. São Paulo: Ateliê, 2005.

CHEVALIER, Jean. Dicionário de símbolos. Rio de Janeiro: José 
Olympio, 2008.

COMBE, Dominique. A referência desdobrada. O sujeito lírico entre a ficção e a autobiografia. In: Revista USP n. 84, 2010.

GAGNEBIN, Jeanne Marie. Filosofia e literatura. In: Limiar - vol.3, n05 - $1^{\circ}$ semestre de 2016.

GURVITCH, Georges. Determinismos sociais e liberdade humana. Rio de Janeiro: Companhia Editora Forense, 1968.

HUTCHEON, Linda. Uma teoria da paródia. Ensinamentos das formas de Arte do século XX. Lisboa: Edições 70, 1985.

JAKOBSON, Roman. O que é poesia? In: TOLEDO, D. (org.) Estruturalismo e semiologia. Porto Alegre: Globo, s/d.

. O que fazem os poetas com as palavras. In: Colóquio/Letras n.12. Lisboa, 02/03/1973.

KANT, Immanuel. Crítica da razão prática. Rio de Janeiro: Ediouro, s/d.

LAPLANCHE, Jean. A angústia. São Paulo: Martins Fontes, 1987.

MAINGUENEAU, Dominique. Do provérbio à ironia: polifonia, captação e subversão. In Análise de textos de comunicação. São Paulo: Cortez, 2008.

MENESES, Adélia Bezerra de. Do poder da palavra: ensaios de literatura e psicanálise. São Paulo: Duas Cidades, 1995.

MERLEAU-PONTY, Maurice. O visível e o invisível. São Paulo: Editora Perspectiva, 2009.

MOURA, Murilo Marcondes de. Manuel Bandeira. São Paulo: Publifolha, 2001.

MUECKE, D. C. Ironia e o irônico. São Paulo: Editora Perspectiva, 
1995.

MUHANA, Adma; BAGOLIN, Luiz Armando (orgs.). Retórica. São Paulo: Annablume, 2012.

NIETZSCHE, Friedrich. Humano, demasiado humano. São Paulo: Companhia das letras, 2005.

NUNES, Benedito. O dorso do tigre: ensaios. São Paulo: Editora Perspectiva, 1969.

PAES, José Paulo. Anatomias. São Paulo: Cultrix, 1961.

. A poesia está morta mas eu juro que não fui eu. São Paulo: Duas Cidades, 1988.

. Entrevista. Revista Cult, n. 40. Dossiê José Paulo Paes. São Paulo: Maio 1999.

PAZ, Octavio. Signos em rotação. São Paulo: Editora Perspectiva, 2012.

REALE, Giovanni. O saber dos Antigos. São Paulo: Loyola, 2011.

REDONDO, Tercio; RUFINONI, Simone Rossinetti. (Org.). Caminhos da lírica brasileira contemporânea: ensaios, 1 ed., São Paulo, Nankin, 2013.

ROSENFELD, Anatol. O teatro épico. São Paulo: Editora Perspectiva, 2011.

SAUSSURE, Ferdinand de. Curso de Linguística Geral. Cultrix: São Paulo, 1975.

SCHMIDT, Joel. Dicionário de mitologia grega e romana. Lisboa: Edições 70, 1994.

STAIGER, Emil. Conceitos fundamentais da poética. Rio de Janeiro: Tempo Brasileiro, 1972. 
SIMON, Iumna Maria. Esteticismo e participação: as vanguardas poéticas no contexto brasileiro (1954-1969). In: Novos Estudos CEBRAP v.26, 1990.

SÜSSEKIND, Pedro. Schiller e a atualidade do sublime. In: SÜSSEKIND (org.). Friedrich Schiller: do sublime ao trágico. Belo Horizonte: Autêntica Editora, 2011.

- Condenados à tradição: o que fizeram com a poesia brasileira. In: Revista Piauí, no 61, outubro de 2001.

VALÉRY, Paul. Variedades. Org. João Alexandre Barbosa. São Paulo: Iluminuras, 1991. 